\title{
Crystallizable Fragment Glycoengineering for Therapeutic Antibodies Development
}

\author{
Wei Li*, Zhongyu Zhu, Weizao Chen, Yang Feng and Dimiter S. Dimitrov* \\ Protein Interactions Section, Cancer and Inflammation Program, Center for Cancer Research, National Cancer Institute, \\ National Institutes of Health, Frederick, MD, United States
}

OPEN ACCESS

Edited by:

Tianlei Ying,

Fudan University, China

Reviewed by:

Johannes S. Gach,

University of California, Irvine,

United States

Yong-Sung Kim,

Ajou University, South Korea

Serge Muyldermans,

Vrije Universiteit Brussel, Belgium

*Correspondence:

Wei Li

wei.li3@nih.gov;

Dimiter S. Dimitrov

dimitrdi@mail.nih.gov

Specialty section: This article was submitted to Vaccines and Molecular Therapeutics,

a section of the journal

Frontiers in Immunology

Received: 19 September 2017

Accepted: 31 October 2017

Published: 13 November 2017

Citation:

Li W, Zhu Z, Chen W, Feng Y and

Dimitrov DS (2017) Crystallizable

Fragment Glycoengineering for

Therapeutic Antibodies Development.

Front. Immunol. 8:1554.

doi: 10.3389/fimmu.2017.01554
Monoclonal antibody (mAb)-based therapeutics are the fastest growing class of human pharmaceuticals. They are typically lgG1 molecules with $\mathrm{N}$-glycans attached to the N297 residue on crystallizable fragment (Fc). Different Fc glycoforms impact their effector function, pharmacokinetics, stability, aggregation, safety, and immunogenicity. Fc glycoforms affect mAbs effector functions including antibody-dependent cellmediated cytotoxicity (ADCC) and complement-dependent cytotoxicity (CDC) by modulating the $\mathrm{Fc}-\mathrm{Fc} \gamma \mathrm{Rs}$ and $\mathrm{Fc}-\mathrm{C} 1 \mathrm{q}$ interactions. While the terminal galactose enhances CDC activity, the fucose significantly decreases ADCC. Defucosylated immunoglobulin Gs (IgGs) are thus highly pursued as next-generation therapeutic mAbs with potent ADCC at reduced doses. A plethora of cell glycoengineering and chemoenzymatic glycoengineering strategies is emerging to produce IgGs with homogenous glycoforms especially without core fucose. The chemoenzymatic glycosylation remodeling also offers useful avenues for site-specific conjugations of small molecule drugs onto mAbs. Herein, we review the current progress of lgG-Fc glycoengineering. We begin with the discussion of the structures of IgG N-glycans and biosynthesis followed by reviewing the impact of IgG glycoforms on antibody effector functions and the current Fc glycoengineering strategies with emphasis on Fc defucosylation. Furthermore, we briefly discuss two novel therapeutic mAbs formats: aglycosylated mAbs and Fc glycan specific antibody-drug conjugates (ADCs). The advances in the understanding of Fc glycobiology and development of novel glycoengineering technologies have facilitated the generation of therapeutic mAbs with homogenous glycoforms and improved therapeutic efficacy.

Keywords: monoclonal antibodies, crystallizable fragment glycosylation, homogenous glycoforms, effector function, crystallizable fragment glycoengineering, chemoenzymatic glycosylation remodeling, aglycosylated monoclonal antibodies, antibody-drug conjugate

\section{INTRODUCTION}

Monoclonal antibody (mAb)-based therapeutics have been the fastest growing class of human pharmaceuticals with applications in various clinical indications such as oncology, inflammatory diseases, organ transplantation, and bacteria and virus infection (1). Currently, more than $60 \mathrm{mAbs}$ and derivatives are approved in USA and Europe for human use with some of them being blockbusters in the biopharmaceutical markets $(2,3)$. Under the vigorous engine of modern translational 
biotechnology, mAbs and derivatives are estimated to be $>30 \%$ of the new licensed drugs (4). Most recombinant therapeutic mAbs are glycosylated immunoglobulin $\mathrm{G}(\mathrm{IgG})$ molecules with glycans attached to the amide nitrogen atom of asparagine 297 (N297) in the crystallizable fragment $(\mathrm{Fc})$ region (Figure 1A) (5). It is well accepted that the N297-attached oligosaccharide is structurally integral to the IgG-Fc with multiple non-covalent interactions with the protein surface of the $\mathrm{C}_{\mathrm{H}} 2$ domain (6). The extensive carbohydrate-polypeptide interactions as well as carbohydrate-carbohydrate interactions modulate the conformations of the IgG molecules, which would ultimately impact the biological functions of mAbs (7).

During the last several decades, substantial knowledge has been acquired regarding the impact of Fc glycosylation on mAbs efficacy, pharmacokinetics (PK), stability, aggregation, safety, and immunogenicity (8-10). Many mAbs exhibit biological functions through immune effector functions including antibody-dependent cell-mediated cytotoxicity (ADCC), antibody-dependent cellmediated phagocytosis (ADCP), and complement-dependent cytotoxicity (CDC) mediated by Fc-Fc $\gamma \mathrm{R}$ and Fc-C1q interactions (11). Alterations of glycoforms impact effector functions through modulating these Fc-ligand interactions (12-14). The effector functions of aglycosylated or deglycosylated IgGs are significantly dampened or eliminated due to the much lower binding to Fc $\gamma$ RI or no binding to FcyRII and FcyRIII (15). Fc $\mathrm{N}$-glycans impact stability of therapeutic antibodies in terms of shelf storage, thermal and chemical stability (such as $\mathrm{pH}$ and urea), aggregation propensity, susceptibility to proteolysis, in vivo clearance rate, and PK properties. The biophysical properties of therapeutic antibodies including the size, mass, charge, solubility, and colloidal stability are affected by $\mathrm{N}$-glycans. Thus, different glycoforms could endow antibodies with distinct physicochemical and storage stabilities. Structurally, the glycans hold together with $\mathrm{Fc}_{\mathrm{H}} 2$ domain with extensive non-covalent interactions, which not only protect the aggregation prone region (Phe241, Phe243, Pro244, Val262, Val264, Val303, and Val305) of $\mathrm{C}_{\mathrm{H}} 2$ from solvent exposure but also contribute to reduce the dynamics of $\mathrm{C}_{\mathrm{H}} 2$ and aid in $\mathrm{C}_{\mathrm{H}} 2$ folding $(16,17)$. These structural features could explain the decreased thermal, chemical stability, and increased aggregation propensity of aglycosylated IgGs compared with the glycosylated counterparts $(16,18,19)$. In addition, the fact that the large complex type $\mathrm{N}$-glycans with terminal galactose support an "open" Fc conformation compared with the "closed" Fc sustained by small glycans indicates $\mathrm{N}$-glycans can also influence the folding of the Fc part (20). On the other hand, N-glycans impact the PK of IgG via modulating IgG sensitivity to serum protease cleavage. Due to the glycans protection, glycosylated IgGs are more resistant to trypsin, chymotrypsin, and pepsin than the aglycosylated IgGs (21). Glycoforms with distinct length, branching, and charge of sugar residues relate to the different susceptibilities of IgGs to proteolysis. While the terminal GlcNAc and sialic acid residues improve the resistance to proteolysis and hence enhance in vivo stability of IgG, terminal galactose residue confers higher sensitivity to proteases (22-24). The other way of selective clearance of glycosylated IgGs is executed by the C-type lectins mediated endocytosis. $\mathrm{N}$-glycans with high mannose or terminated with GlcNAc could bind to the mannose receptors on macrophages/dendritic cells leading to the accelerated clearance of IgGs $(25,26)$. IgG with terminal galactose residue could be bound and cleared by the asialoglycoprotein receptor expressed in the hepatocytes (27). Besides, mAbs glycosylation also correlates with their immunogenicity and safety in humans.
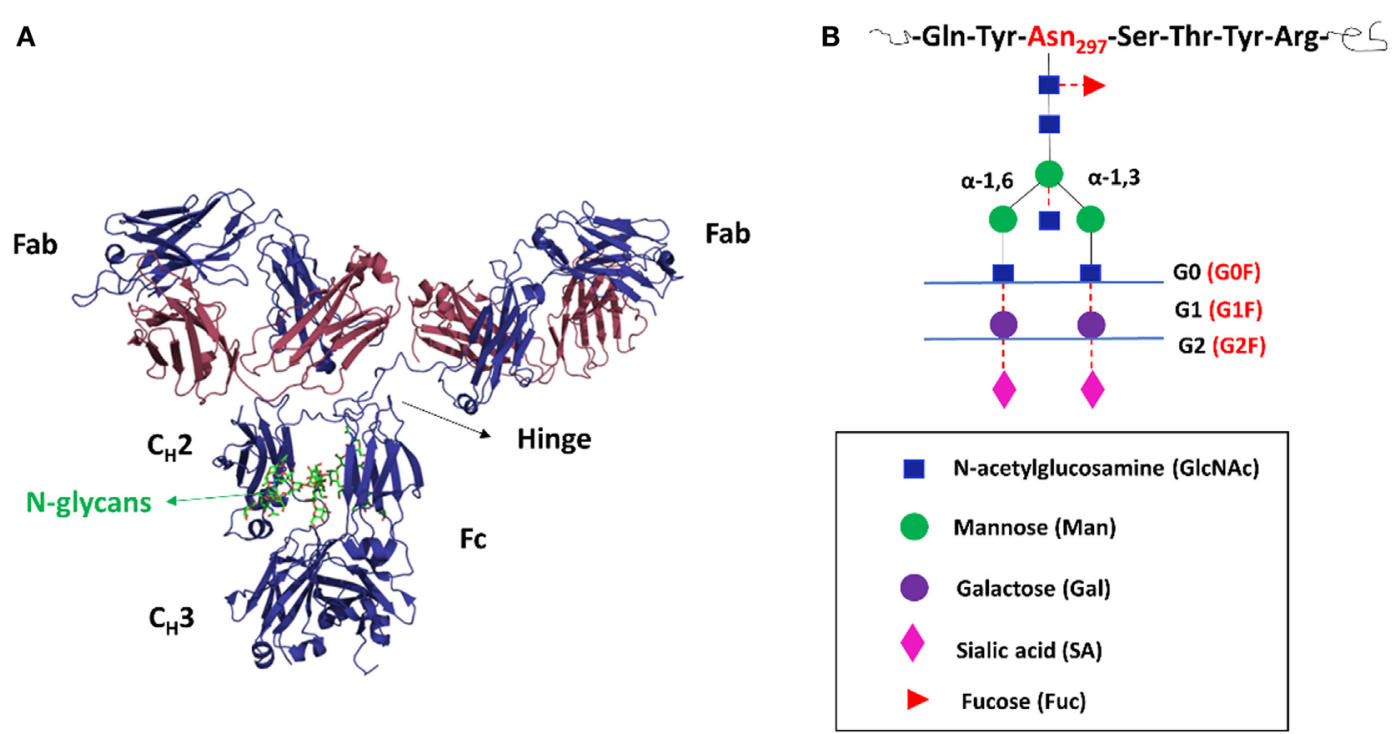

FIGURE 1 | The structures of immunoglobulin G (lgG) and N-glycans. (A) Cartoon representations of a full-length lgG showing the functional domains. An IgG

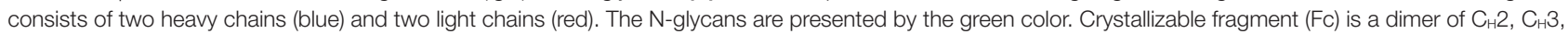
and glycans. Antigen-binding fragment (Fab) is composed of variable heavy and light domains, as well as two constant domains (CH1 and $\mathrm{CL}$ ). (B) The schematic structures of the possible biantennary oligosaccharides attached to human IgG-FC at N297. The core heptasaccharide (G0) is linked in black lines; the outer arm sugar residues are attached to the core by the red dash line. 
Therapeutic mAbs heterologously produced in $\mathrm{CHO}$ and murine myeloma cells (Sp2/0 and NS0 cells) possess non-natural sugars compared with human IgG, such as $N$-glycolylneuraminic acid (NGNA) residues and terminal $\alpha$-1,3-linked galactose, which could induce potential immunogenicity in humans $(28,29)$.

Given its importance, glycosylation is considered a critical quality attribute for mAb therapeutics (30). The regulatory authorities require developers to keep glycoforms humanized and consistent with limited heterogeneity. Hence, developers need to strictly control the glycosylation profile during the development and production of mAbs. However, mAbs glycosylation is intrinsically heterogenous since glycans biosynthesis is not directly template driven. It is the product of sets of biochemical reactions involving a complex network of metabolic enzymes, which depends on the availability of sugar-nucleotide substrates, the enzyme distribution in the host cell, orchestrated process in endoplasmic reticulum (ER) and Golgi bodies and environmental factors $(31,32)$. Consequently, it is very challenging to achieve a highly homogenous glycoform independent of fermentation batches when expressing mAbs in eukaryotic cells. In the past decade, with significant advances in molecular and cell biology, protein and antibody engineering and gene editing, researchers have demonstrated individual glycoforms of antibodies could provide optimal efficacy for selected indications (Table 1) $(33,34)$. The pharmaceutical industry is increasingly pursuing the next-generation mAbs with tailored therapeutic effects. Herein, we review the current progress of $\mathrm{mAbs} F c$ glycoengineering. We first present structures and biosynthesis of Fc N-glycans, followed by the discussion of impact of mAbs glycosylation on effector functions and the current glycoengineering strategies with emphasis on Fc defucosylation. Furthermore, we briefly discuss two novel therapeutic mAbs formats involving Fc glycans: aglycosylated $\mathrm{mAbs}$ and $\mathrm{N}$-glycans targeted site-specific antibody-drug conjugates (ADCs).

\section{IgG-FC N-GLYCANS STRUCTURES AND BIOSYNTHESIS}

The IgG-Fc N-glycan is usually of limited size with no more than three antennae (33). Typically, oligosaccharides of normal human IgGs are biantennary complex structures with a core heptasaccharide and an outer arm of sugar residues (6) (Figure 1B). The core oligosaccharide (GlcNAc2Man3GlcNAc2, designated as G0) is composed of two inner GlcNAc, three mannoses, and two GlcNAc $\beta-1,2$ linked to $\alpha-3$ and $\alpha-6$ mannose forming two antennae ( $\alpha-3$ arm and $\alpha-6$ arm). One major feature of IgG-Fc glycans is the microheterogeneity, which not only stems from the linkage of sugar isomers and glycosylation site occupancy but also results from the outer arm sugar addition depending on the expression system and glycosylation enzymatic machinery $(31,64)$. Such additions include fucose (Fuc, G0F), galactose (Gal, G1, and G2), bisecting GlcNAc (linked to the core GlcNAc-associated mannose, which is catalyzed by GlcNAc transferases III), and sialic acid including $N$-acetylneuraminic acid (NANA) or $N$-glycolylneuraminic acid (NGNA) residues (9). In addition, structural studies have shown that the two $\mathrm{N}$-glycans from every heavy chain are asymmetrically oriented $(65,66)$, which further diversifies IgG-Fc glycoforms. Consequently, Fc N-glycans possess more than 400 glycoforms considering random pairing of two different heavy chain glycans (67). Human serum IgG-Fc glycans typically contain 30\% G0F, $\sim 35 \%$ G1F, $\sim 16 \%$ G2F, and $\sim 15 \%$ bisecting GlcNAc (68). Low levels of sialylation are observed in human IgG-Fc glycans with monosialylated and disialylated glycoforms accounting for approximately 5-10 and 1\%, respectively (69). Interestingly, mAbs produced in recombinant expression systems share similar $\mathrm{N}$-glycans structures with IgGs from human serum (13). MAbs produced in $\mathrm{CHO}, \mathrm{NS} 0$, and $\mathrm{Sp} 2 / 0$ cell lines have predominant glycoforms of G0F, G1F, G2F, a paucity of sialylated glycans and do not contain bisecting $\operatorname{GlcNAc}(34,70)$.

Like other glycoproteins, glycosylation of IgG occurs through the conserved ER and Golgi glycosylation pathway (32). $\mathrm{N}$-glycosylation begins with the addition of a pyrophosphatedolichol precursor (Dol-P, Glc3Man9GlcNAc2) to the consensus $\mathrm{N}$-glycosylation sequon (Asn-X-Ser/Thr, where $\mathrm{X}$ is any amino acid except Pro) of a nascent polypeptide by a transmembrane oligosaccharyltransferase (Figure 2) (71). Thereafter, the $\mathrm{N}$-glycans are subjected to series of sequential modifications by sets of glycosidases and glycosyltransferases. In the lumen of the ER, polypeptide associated Glc3Man9GlcNAc2 is sequentially trimmed by glucosidases I and II and endo-mannosidase to yield

TABLE 1 | Selected glycosylation engineering of therapeutic antibodies for targeted diseases.

\begin{tabular}{|c|c|c|c|c|c|}
\hline mAbs name & Target & Indication & Glycol modification & Development status & Reference \\
\hline Otelixizumab & CD3 & Type I diabetes, rheumatoid arthritis & Aglycosylated & Phase I (completed) & (35) \\
\hline MTRX-1011A & CD4 & Rheumatoid arthritis, cutaneous lupus & Aglycosylated & Phase I (completed) & (36) \\
\hline Mogamulizumab & CCR4 & ATLL, CTCL & Afucosylated & Approved & $(37,38)$ \\
\hline MDX-1342 & CD19 & Relapsed or refractory CLL & Afucosylated & Phase I & (39) \\
\hline Obinutuzumab & CD20 & CLL, follicular lymphoma & Low fucose & Approved & $(40)$ \\
\hline DI-B4 & CD19 & CD19-positive indolent B-cell lymphoma & Low fucose & Phase I & (41) \\
\hline RG7160 & EGFR & EGFR-positive solid tumors & Bisected; non-fucosylated & Phase II & $(42)$ \\
\hline GTMAB2.5GEX & Mucin 1 & A-MUC1-positive ovarian cancer & Glycooptimized & Phase II & (43) \\
\hline Rituximab & CD20 & CLL and NHL & Galactosylated & NA & $(44)$ \\
\hline Intravenous immunoglobulin & NA & Autoantibody-driven inflammation & Sialylated & NA & (13) \\
\hline
\end{tabular}

CCR4, C-C chemokine receptor type 4; EGFR, epidermal growth factor receptor; ATLL, adult T-cell leukemia/lymphoma; CTCL, Cutaneous T-cell lymphomas; CLL, chronic lymphocytic leukemia; NHL, non-Hodgkin's lymphoma; NA, not applicable; mAb, monoclonal antibody. 


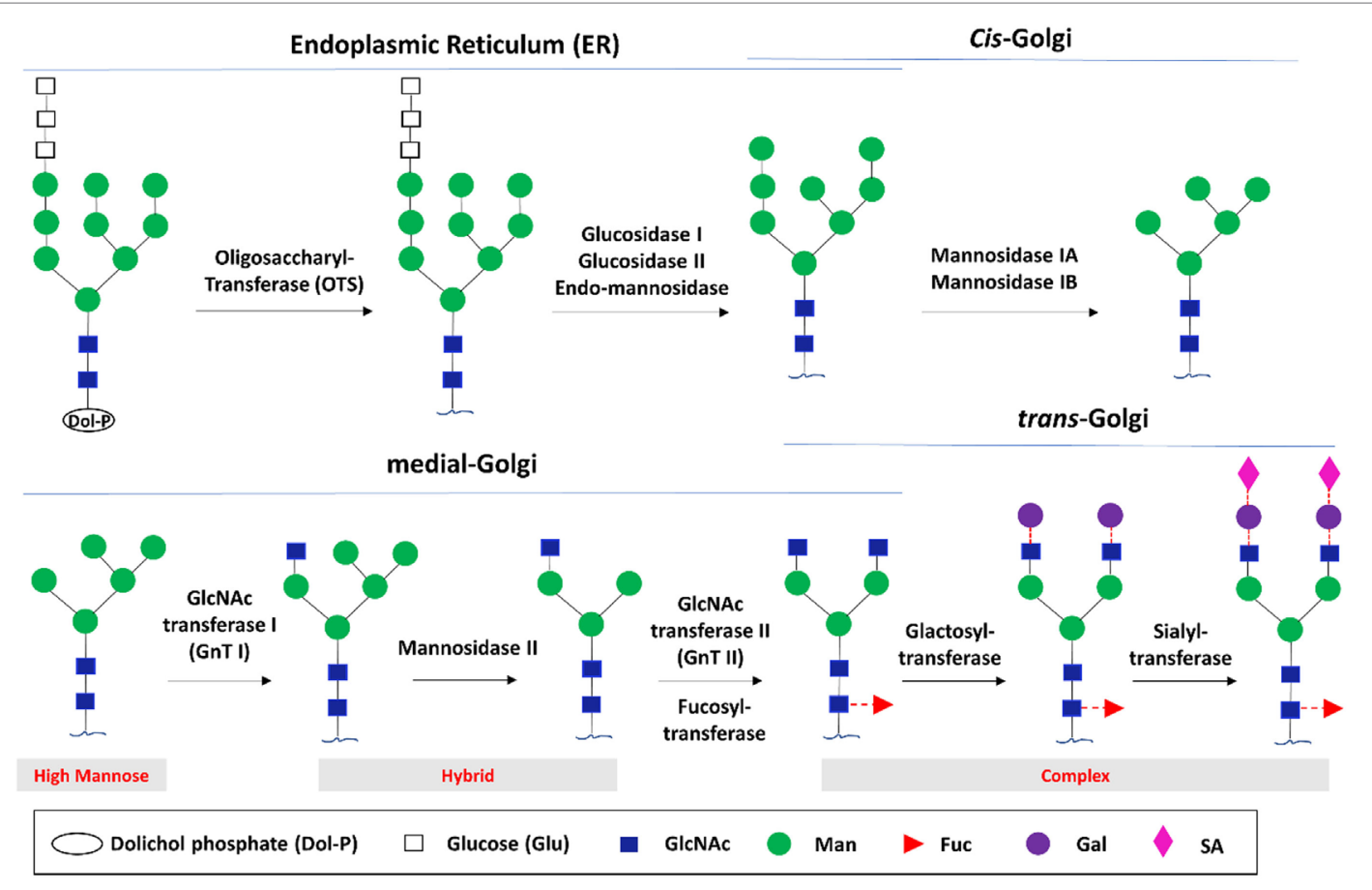

FIGURE 2 | Glycan biosynthesis through the endoplasmic reticulum (ER) and Golgi glycosylation pathway. The biosynthesis begins with the processing of the initial high mannose $\mathrm{N}$-glycan in the ER followed by transferring into the cis-Golgi to generate the core N-glycan substrate used for further diversification in the trans-Golgi. The potential glycoforms include the high mannose, hybrid, and complex structure.

Man8GlcNAc2 (72). This process is under protein folding quality control mediated by calnexin-calreticulin complex. In the cisGolgi, the Man8GlcNAc2 is sequentially processed by two class I $\alpha$-mannosidases that act specifically on $\alpha$-1,2-Man residues to give rise to the core Man5GlcNAc2 glycan for further diversification in the medial and trans-Golgi, which include stepwise addition of the outer arm monosaccharide residues, catalyzed by GlcNAc transferases I, II, and III (GnT I, II, and III), fucosyltransferases, galactosyltransferases (GalT), and sialyltransferases (SiaT).

\section{IMPACT OF FC GLYCOSYLATION ON IgG EFFECTOR FUNCTIONS}

Crystallizable fragment glycoforms affect the effector function of antibodies by modulating the fine structure of Fc and thus altering Fc-ligands interactions. In recent years, structural insights into how antibody Fc glycoforms impact effector functions have been acquired by X-ray crystallography, nuclear magnetic resonance spectroscopy, and thermodynamics studies. Due to the stabilization effect of protein-sugar interaction, the core structures of GlcNAc2Man3 on the 1,3 arm and 1,6 arm are usually visible in the crystal structures. These two arms adopt distinct orientations-the 1,6 arm hangs over the hydrophobic face of $\mathrm{C}_{\mathrm{H}} 2$ domain while the $1,3 \mathrm{arm}$ is orientated toward the internal space within the $\mathrm{C}_{\mathrm{H}} 2$ dimer (73). The oligosaccharide is well conserved and spans over $500 \AA^{2}$ of the surface of each $\mathrm{C}_{\mathrm{H}} 2$ domains (20) (Figure 3A). Oligosaccharides make multiple hydrophobic and polar non-covalent interactions with the inner face of the $\mathrm{C}_{\mathrm{H}} 2$ domain (74). Impressive interactions include D265 hydrogen bonding to the inner GlcNAc and the $\alpha-1,6$ arm forming strong $\mathrm{CH}-\pi$ packing with Phe241 and 243, which restricts the mobility of the glycans (75). Reciprocally, these intramolecular interactions restrain the $\mathrm{C}_{\mathrm{H}} 2$ conformation by stabilizing the $\mathrm{C}^{\prime} \mathrm{E}$ loop where the Asn297 locates, through which N-glycans pre-organize the ligands (FcyRs and $\mathrm{Clq}$ ) binding interface on $\mathrm{Fc}$ (15). Besides, carbohydrate-carbohydrate interactions also contribute to maintain Fc conformation. The reciprocal mannoses from the two heavy chains make $s p-s p$ contacts with each other (Figure 3B), which is necessary to establish a proper Fc conformation for ligand binding (14).

Multifaced impacts of terminal sugars on the antibody effector function have been elucidated. While high mannose, low fucose, and bisecting GlcNAc increase ADCC due to enhanced Fc $\gamma$ RIIIa binding, terminal sialic acid decrease ADCC of IgG (14). For CDC, terminal galactose increases CDC by improving $\mathrm{C} 1 \mathrm{q}$ binding, whereas terminal GlcNAc and sialic acid decrease CDC (12). Among these effects, reduction in fucose and terminal galactose, which improves ADCC and CDC, is highly desirable in antibody glycoengineering (76). Regulating $\alpha$-2,6-linked terminal sialic acid is also an attractive strategy due to the anti-inflammatory role of these terminal sialic acid (77).

\section{Absence of Core Fucose Results in Improved ADCC Activity of IgG}

Addition of a fucose to the innermost GlcNAc (the core fucose) is catalyzed by the $\alpha-1,6$-fucosyltransferase in the medial-Golgi. 


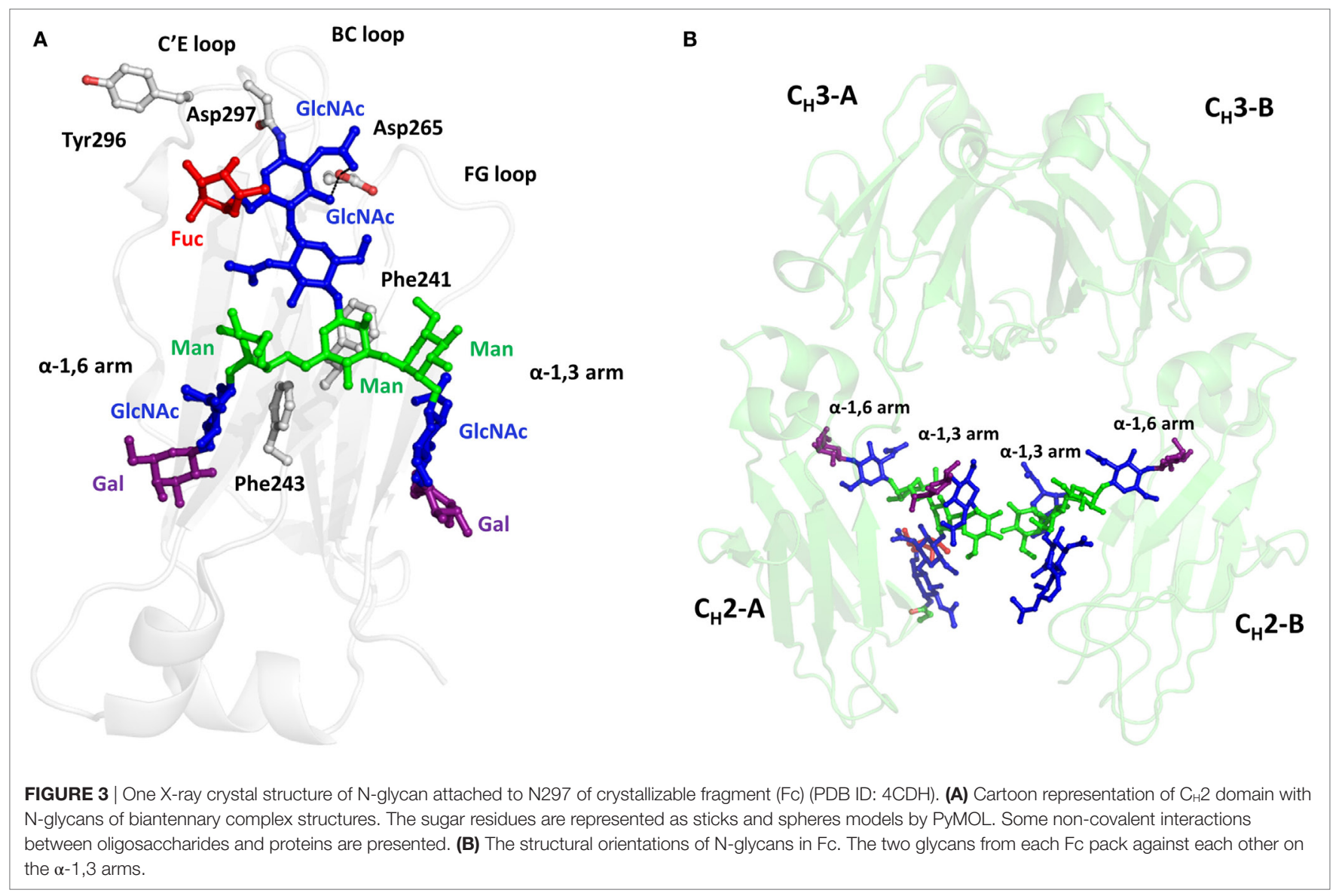

More than $80 \%$ of the human IgG and $>90 \%$ of the recombinant IgG produced by CHO cells contain the core fucose (13). However, the absence of core Fuc residue in the N-glycans significantly improves ADCC activity of IgG due to the substantially enhanced binding affinity to Fc $\gamma$ RIIIa $(31,75)$. For example, afucosylated anti-HER2 IgG exhibits a 100 -fold greater ADCC effect compared with the fucosylated counterpart (51). The defucosylated antibody is also more potent than the fucosylated counterpart in the clinic $(37,78)$. The resolved complex crystal structures of Fc-FcyRIIIa have provided molecular rationales underlying the enhanced binding to Fc $\gamma$ RIIIa for defucosylated IgGs. The crystal structure of sFcyRIIIa with high mannose-type glycans in Asn162 complexed with the defucosylated Fc show that the lower hinge regions of $\mathrm{C}_{\mathrm{H}} 2$ dimer dock onto the D2 domain of FcyRIIIa (79). Both the carbohydrate-carbohydrate and carbohydrate-protein interactions exist at the interface. The chitobiose core of Asn162 glycans hydrogen bond to the innermost GlcNAc of Fc. The 1,3-arm mannose of Fc $\gamma$ RIIIa forms a hydrogen bond to the Gln295 of Fc. The branching $\beta$-mannose and Lys128 of Fc $\gamma$ RIIIa make contacts with Tyr296 residue of Fc (Figure 4). However, these non-covalent interactions were unfavorable or disrupted due to the steric hindrances imposed by the presence of fucose in the fucosylated Fc. Besides, the conformation of Tyr296 is more constrained in the fucosylated Fc, which prevents Tyr296 from adapting a favorable conformation for binding to Fc $\gamma$ RIIIa (80). Thus, the fucose moiety exerts allosterically inhibitory effects on the Fc-FcyRIIIa interaction, although it does not contact directly with FcyRIIIa. The enhanced binding affinity to FcyRIIIa endows defucosylated IgG several therapeutic merits. First, the high affinity could make the exogenous defucosylated IgG outcompete the endogenous serum IgG, thus avoiding the inhibitory effects of high concentration of serum IgGs on therapeutic IgG efficacies. For example, the inhibitory effect of endogenous IgG on ADCC was alleviated by defucosylated anti-CD20 antibodies $(81,82)$. Second, defucosylated antibodies have enhanced binding to the low affinity allotype of Fc $\gamma$ RIIIa-158F and reduce the differences of ADCC efficacies of antibodies among the FcyRIIIa-158V and Fc $\gamma$ RIIIa-158F allelic patients. Defucosylated IgGs have broader applications for all patients independent of the Fc $\gamma$ RIIIa polymorphisms $(83,84)$. Finally, in addition to enhanced activation of Fc $\gamma$ RIIIa-expressing killer cells (NK cells, monocytes, and macrophages) to mediate ADCC, the defucosylated antibody has also been reported to evoke ADCP effect through engaging Fc $\gamma$ RIIIb on neutrophils, which in turn facilitates antigen presentation and recruitment of adaptive immunity, as evidenced by the defucosylated anti-CD20 IgG mediating upregulation of MHC class II molecules on neutrophil cell surface (85). Collectively, Fc fucosylation represents the most important influencer in modulating IgG effector function. Since ADCC is the main mode of action for mAbs in clinical oncology, defucosylated IgGs are highly desirable as the next-generation 


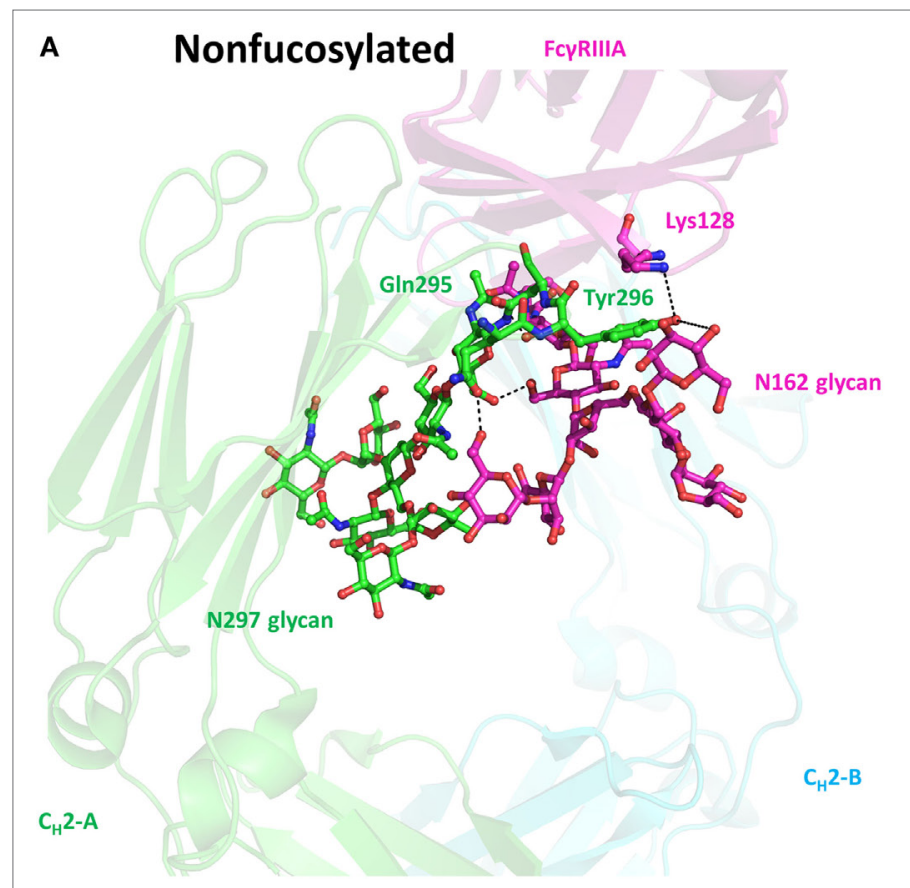

B Fucosylated FcүRIIIA

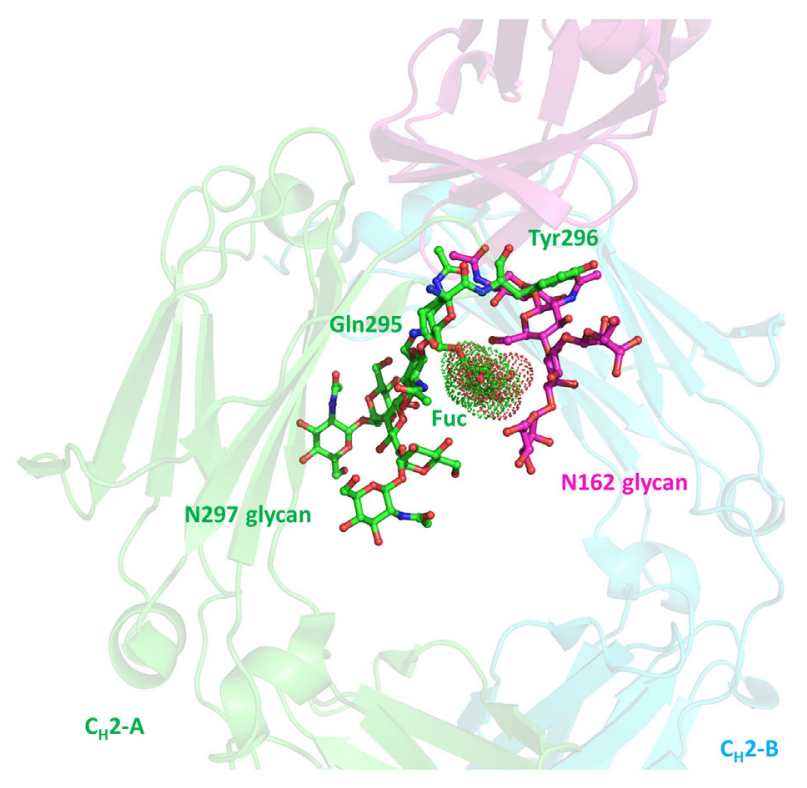

FIGURE 4 | The crystal structures of non-fucosylated crystallizable fragment (FC) (PDB ID: 3SGK) and fucosylated Fc (PDB ID: 3SGJ) complexed with FCyRIlla with a high mannose glycan on N162. (A) Cartoon representation of non-fucosylated FC-FcyRIlla complex produced by PyMOL. The oligosaccharides and part of hydrogen bonding formation residues are shown in sphere and stick representation. The hydrogen bonds are depicted as black dash lines. (B) Cartoon representation of fucosylated Fc-FcyRllla complex. The core fucose locating at the interface of Fc N297 glycan and Fc $\gamma$ RIlla N162 glycans is highlighted with the dot representation.

therapeutic antibodies. The high demand in defucosylated $\mathrm{mAbs}$ is driving the development of multiple glycoengineering strategies to produce low fucose antibodies (see below Table 2).

\section{High Galactose Enhances CDC Activity of IgG}

Both human serum IgG and recombinant IgG contain predominantly terminal galactose residues in their antennae (31). $\mathrm{CHO}$ cells-derived IgGs usually have lower levels of galactosylation compared with IgGs produced in mouse myeloma cells (32). Although the terminal galactose does not affect ADCC activity of IgG, it plays an important role in modulating the CDC activity (86). For example, the galactosylated rituximab exhibited higher CDC than the degalactosylated glycoform due to the higher affinity to C1q (44). Structurally, the extensive hydrophobic and hydrophilic interactions between terminal Gal residue and protein could impact the conformation of the $\mathrm{C}_{\mathrm{H}} 2$ domain, resulting in altered C1q binding (20). More hydrogen bonds between sugar residues and amino acids are found in the G2 glycoform compared with the G0 form of IgG1 (Figure 5) $(14,87,88)$. Consequently, the stretch from residue 244 to 247 of $\mathrm{C}_{\mathrm{H}} 2$ domain is destabilized in the G0 glycoform, which was also supported by the comparative differential scanning microcalorimetry showing that G0 form associates with a lower enthalpy than the G2 form (89). These studies suggest that the non-covalent interactions between galactose and amino acid residues may account for the increased binding affinity between galactosylated Fc and C1q. Although the role of terminal galactose is not completely elucidated and in some cases the effect of terminal galactose has been reported to be antibody dependent, a proper control of galactosylation during manufacturing is still warranted.

\section{Impact of Terminal Sialylation on IgG Functions}

The terminal sialic acid residue prolongs IgG half-life in the serum by shielding "galactose" residues from exposure to galactose-specific receptors in hepatocytes (32). On the other hand, sialylation may be undesirable because it renders IgGs more sensitive to protease compared with asialylated antibodies, probably due to the bulkier sialic acid leading to structural perturbations of $\mathrm{C}_{\mathrm{H}} 2$ domains $(22,90)$. The crystal structure has shown that the 1,6-arm sialic acid poses away from the proteinassociated galactose residue and is entirely exposed to the solvent (91). The $\alpha-2,3$-sialylation negatively impacts the canonical galactose-protein interactions and potentially destabilizes the $\mathrm{C}_{\mathrm{H}} 2$ domain (92). In addition, sialylation has negative effect on the ADCC activity of mAb (93), which may either stem from the decreased hinge flexibility upon sialylation causing reduced Fc $\gamma$ RIIIa binding, or from the reduced bivalent antigen binding due to the lack of hinge flexibility (94). Antibody sialylation is desired due to its anti-inflammatory effects with potential applications in autoimmune and inflammatory diseases (95). The effect of sialylation was first discovered from human intravenous immunoglobulin but can also be recapitulated by the $\alpha$-2,6-sialylation in recombinant IgG (96). Although not fully understood, this anti-inflammatory effect is triggered by the 
TABLE 2 | Summary of the cell glycoengineering strategies to produce defucosylated antibodies.

\begin{tabular}{|c|c|c|c|c|c|c|c|c|}
\hline Cell type & & & $\begin{array}{l}\text { Glycoengineering } \\
\text { modification }\end{array}$ & $\begin{array}{l}\text { Company and technology } \\
\text { platform }\end{array}$ & Antibody name & Targets & $\begin{array}{l}\text { Development } \\
\text { status }\end{array}$ & Reference \\
\hline \multirow{2}{*}{$\begin{array}{l}\text { Non- } \\
\text { mammalian } \\
\text { cells }\end{array}$} & \multicolumn{2}{|l|}{ Yeasts } & och or alg3 $\mathrm{KO}$ & $\begin{array}{l}\text { NA } \\
\text { GS4.0 }\end{array}$ & Rituximab & Anti-CD20 & NA & $(45-47)$ \\
\hline & \multicolumn{2}{|l|}{ Plants } & RNAi of $\beta-1,2$-XylT and $\alpha-1,3$-FucT & MAPP Biopharmaceutical & ZMAPP & Anti-Ebola & Phase 2/3 & $(48,49)$ \\
\hline \multirow[t]{13}{*}{$\begin{array}{l}\text { Mammalian } \\
\text { cells }\end{array}$} & \multicolumn{2}{|l|}{ YB2/0 } & \multirow{2}{*}{$\begin{array}{l}\text { Intrinsic low core fucose content } \\
\text { YB2/0 (FUT8 low); Lec13 } \\
\text { (GMD low) }\end{array}$} & $\begin{array}{l}\text { LFB Biotechnologies } \\
\text { EMABling Technology }\end{array}$ & Ublituximab; roledumab & Anti-CD20; anti-RhD & Phase 2/3 & (50) \\
\hline & \multirow[t]{11}{*}{$\mathrm{CHO}$ cells } & Lec13 cells & & Biowa & Hu4D5 & Anti-HER2 & NA & (51) \\
\hline & & WT CHO & $\begin{array}{l}\text { Addition of sugar analog into } \\
\text { culture medium (process } \\
\text { engineering) }\end{array}$ & $\begin{array}{l}\text { Seattle Genetics } \\
\text { SEA Technology }\end{array}$ & SEA-CD40 & Anti-CD40 & Phase 1 & (52) \\
\hline & & \multirow[t]{9}{*}{$\begin{array}{l}\text { Genetically } \\
\text { modified CHO }\end{array}$} & GMD KO & GMD knockout CHO/DG44 & Rituximab & Anti-CD20 & NA & (53) \\
\hline & & & RMD overexpression & ProBioGen, GlymaxX Technology & Trastuzumab & Anti-HER2 & NA & (54) \\
\hline & & & GFT KO & CRISPR-Cas9 KO GFT CHO-F6 & LSEVh-LS-F & Anti-HIV-1 Env & Pre-clinic & $(55,56)$ \\
\hline & & & \multirow[t]{2}{*}{ GnT III overpression } & \multirow{2}{*}{$\begin{array}{l}\text { Roche } \\
\text { GlycoMab Technology }\end{array}$} & Obinutuzumab & Anti-CD20 & Approved & (57) \\
\hline & & & & & RG7116 & Anti-HER3 & Phase 1 & (58) \\
\hline & & & RNAi of FUT8 and/or GMD & FG16 & KM2160 & Anti-CCR4 & NA & $(59,60)$ \\
\hline & & & \multirow[t]{3}{*}{ FUT8 KO } & \multirow{2}{*}{$\begin{array}{l}\text { Kyowa Hakko Kirin } \\
\text { Potelligent Technology }\end{array}$} & Mogamulizumab & Anti-CCR4 & Approved & (61) \\
\hline & & & & & $\begin{array}{l}\text { Benralizumab, ecromeximab, } \\
\text { MEDI-551, BIW-8962, } \\
\text { KHK2804, 2823, 2898, } 4083\end{array}$ & $\begin{array}{l}\text { Anti-IL-5R } \alpha, \text { GD3, } \\
\text { CD19, GM2, CD123, } \\
\text { CD98 }\end{array}$ & In clinical trials & (31) \\
\hline & & & & FUT8 knockout CHO/DG44 & NA & Anti-CD20 & NA & (62) \\
\hline & \multicolumn{2}{|l|}{$\begin{array}{l}293 \text { FreeStyle } \\
\text { cells }\end{array}$} & $\alpha$-Mannosidase inhibitors kifunensine & NA & $4 \mathrm{Dm} 2 \mathrm{~m}-\mathrm{F}$ & Anti-HIV-1 Env & NA & (63) \\
\hline
\end{tabular}

NA, not applied; RhD, rhesus D antigen; GFT, GDP-fucose transporter; GM2, ganglioside mono-sialic acid 2; GD3, ganglioside di-sialic acid 3; GMD, GDP-mannose 4,6-dehydratase; GnT III, GIcNAc transferase III. 

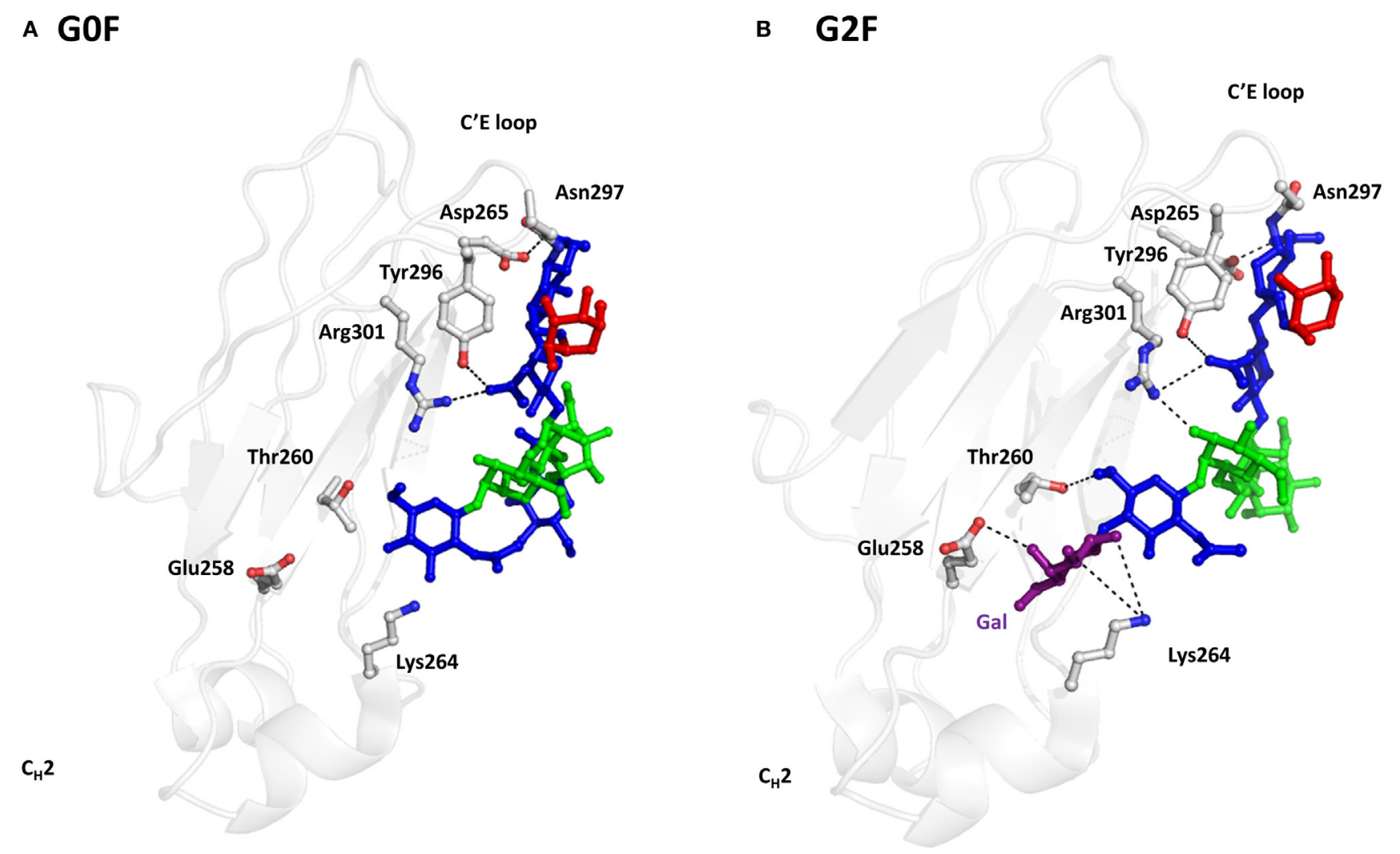

FIGURE 5 | Representative crystal structures of IgG1 GOF, and G2F glycoforms. (A) The crystal structure of GOF. N-glycans and amino acids involving hydrogen bond formation are depicted by stick and sphere models. $\mathrm{C}_{\mathrm{H}} 2$ domain is represented as gray cartoon. The blue, green, and red colors represent GlcNAc, Man, and Fuc, respectively. Hydrogen bonds are drawn by black dash lines. (B) The crystal structure of G2F. The purple stick represents Gal, which engages several hydrogen bonds with nearby polar amino acids.

sialylated IgG interacting with the murine C-type lectin-like receptor-specific intracellular adhesion molecule-grabbing non-integrin R1 (SIGN-RI) on macrophage and dendritic cells (human ortholog, DCSIGN), which leads to increased Fc $\gamma$ RIIb expression and expansion of Treg cell populations suppressing of inflammatory response $(97,98)$. Collectively, terminal sialic acid residues have both positive and negative effects on antibodies biological functions. It is necessary to strictly control sialylation in recombinant IgGs.

\section{IgG-Fc GLYCOENGINEERING}

Since different glycoforms have distinct impacts on antibody effector function, it is necessary to control antibody glycoforms. With advanced knowledge of glycobiology, it is feasible to produce homogeneously glycosylated antibodies with tailored effector function. Strategies include host cell based glycoengineering involving manipulations of biosynthetic pathways and in vitro chemoenzymatic glycosylation remodeling.

\section{Cell Glycoengineering}

Host cell glycoengineering has been highly pursued in recent years to produce recombinant IgG with desired glycoforms. As mentioned above, antibody glycoforms resulting from sets of enzymatic reactions pathways are a combined function of host cells, enzyme kinetical parameters, nucleotide sugar substrates, and the external factors. Following this lead, we classify cell glycoengineering strategies into the following four types.

\section{Selection of Cell Type, Environmental Factors, and Cell Culture Conditions}

Antibody glycosylation is largely influenced by the host cells from which they are manufactured. mAbs produced by $\mathrm{CHO}$ cells are somewhat under-sialylation due to the lack of $\alpha-2$, 6 -sialyltransferase in these cells (31). Host cells with intrinsically low $\alpha-1,6$ fucosyltransferase activity could be used to produce IgGs with low core fucose (99). For example, the rat hybridoma cell line YB2/0 with low FUT8 activity, a type of $\alpha-1,6$ fucosyltransferase responsible for adding the core fucose, is used for the productions of defucosylated IgG (50). Another example is the Lec13 cell line, a derivative of $\mathrm{CHO}$ cells with deficiency in GDP-mannose 4,6-dehydratase (GMD) function leading to low fucosylation (51). On the other hand, the cell culture environment could be manipulated during the fermentation process to alter and optimize antibody glycoforms (process glycoengineering) (32). For example, addition of uridine, manganese chloride, and galactose could increase terminal $\mathrm{Gal}$ to enhance $\mathrm{CDC}$ activity of $\operatorname{IgG}(76,100)$. Addition of UDP-GlcNAc and using 
serum-free culture increased sialylation of IgG1 (101). Addition of modified sugars such as 2-fluorofucose to the culture medium inhibits core fucose incorporation (102).

\section{Using Enzyme Inhibitors to Intervene Host Biosynthesis Pathway}

Inhibitors able to modulate mAbs glycosylation have been reported. Antibody glycosylation is the result of multiple stepwise events. Enzyme inhibitors arresting $\mathrm{mAbs}$ in the intermediate glycoforms could prevent the additions of outer arm sugar residues including fucose (13). Such examples include the ER glucosidases I and II inhibitors, deoxynojirimycin and castanospermine producing Glc3Man9GlcNAc2 glycoform; the ER $\alpha$-mannosidase inhibitors, deoxymannojirimycin and kifunensine producing the high mannose (Man9GlcNAc2) glycoform; and Golgi $\alpha$-mannosidase II inhibitor swainsonine producing hybrid glycoforms such as GlcNAcMan5GlcNAc2Fuc (103). The authors' group has used kifunensine to produce a defucosylated IgG-like bispecific and multivalent anti-HIV-1 molecule, 4Dm2m-F (63). 4Dm2m-F exhibits approximately threefolds higher binding affinity to FcyRIIIa than fucosylated $4 \mathrm{Dm} 2 \mathrm{~m}$ (Figure 6). The ADCC activity of $4 \mathrm{Dm} 2 \mathrm{~m}-\mathrm{F}$ is also significantly improved based on the Promega ADCC reporter assay.

\section{Genetic Modifications of the Host Biosynthesis Pathway}

Antibody glycoforms can be altered by modulating host $\mathrm{N}$-glycosylation pathway. The substrate availability can be changed by inactivation or overexpression of the corresponding nucleotide sugar transporters. For example, knockout of the mammalian GMD gene decreases the synthesis of the fucose donor, GDPfucose, leading to production of defucosylated IgG (104). A similar method involves the overexpression of the GDP-6-deoxy-D-lyxo4-hexulose reductase (RMD) (ProBioGen, GlymaxX technology) (105). In another example, co-transfection of cytidine monophosphate-sialic acid synthase, cytidine monophosphate-sialic acid transporter, and $\alpha-2,3-\mathrm{SiaT}$ in $\mathrm{CHO}$ cell lines significantly has increased the intracellular CMP-SA level and improved the SA content of the recombinant protein (106). Recently, the gene editing technology is also used to engineer defucosylated antibodies. ZFNs and TALENs were used to inactivate GDP-fucose transporter (GFT) gene (Slc35c1) in CHO cells for production of fucose-free antibodies (107). Our group recently has used CRISPR-Cas9 to knockout GFT gene in $\mathrm{CHO}$ cell line (termed as $\mathrm{CHO}-\mathrm{F} 6$ ) for the production of various afucosylated $\mathrm{mAbs}$ and $\mathrm{Fc}$-fusion proteins (Figure 7) (55). Alternatively, the unwanted glycan pathways could be outcompeted by desired ones. For example, Roche's GlycArt

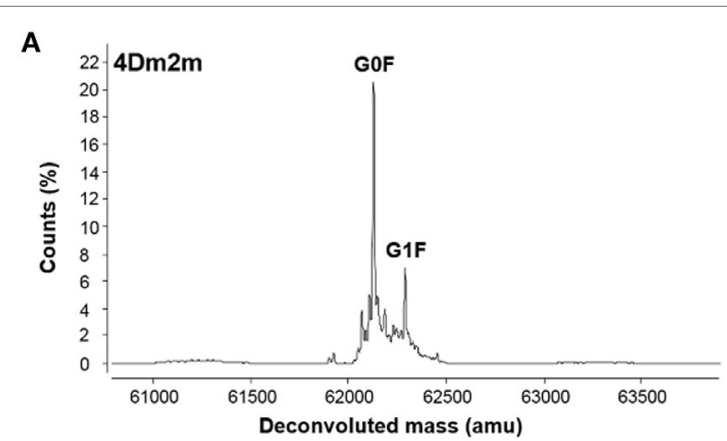

C

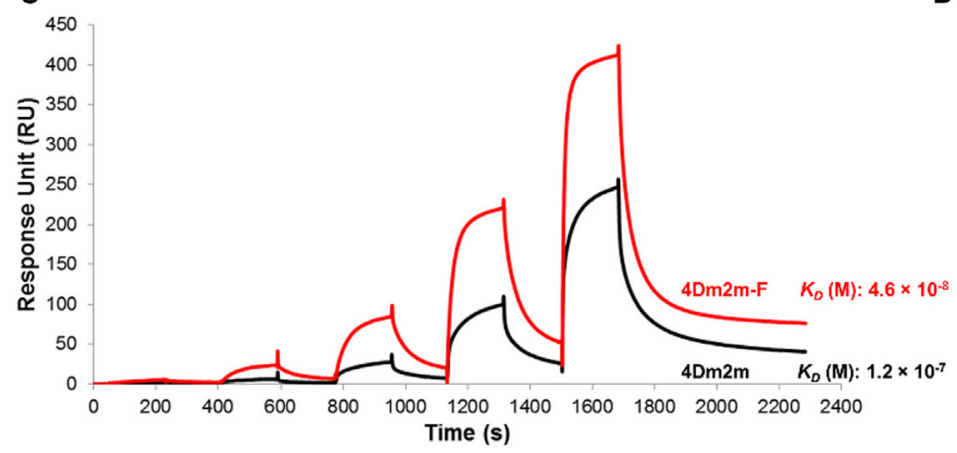

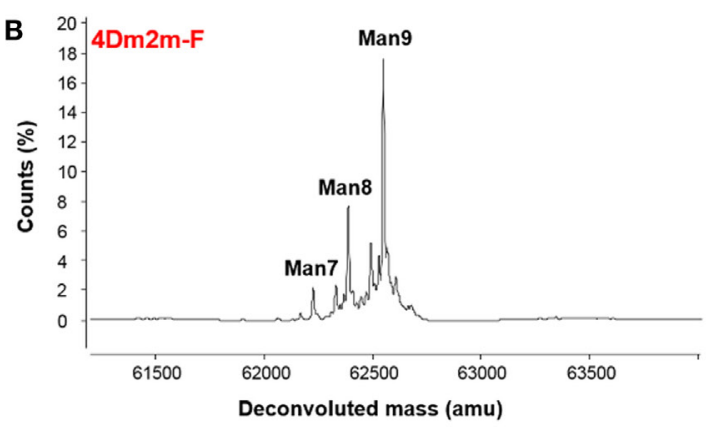

D

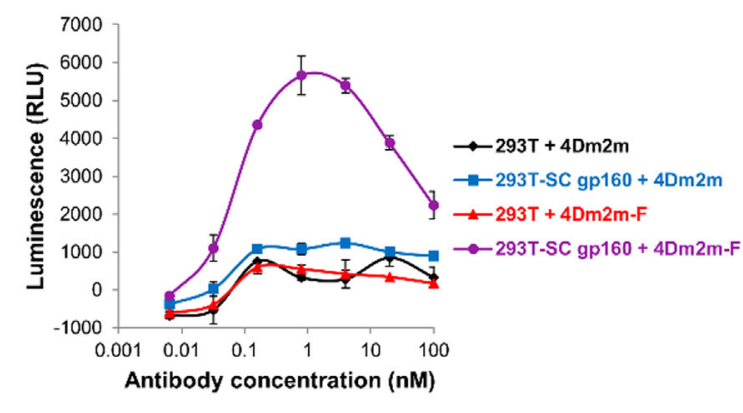

FIGURE 6 | Use of the endoplasmic reticulum $\alpha$-mannosidase inhibitors, kifunensine, to produce the high mannose glycoform with low fucose. (A,B) Deconvoluted mass spectra for heavy chains of $4 \mathrm{Dm} 2 \mathrm{~m}$ produced in the culture medium without (A) or with addition of kifunensine (B). $4 \mathrm{Dm} 2 \mathrm{~m}$ and $4 \mathrm{Dm} 2 \mathrm{~m}-\mathrm{F}$ were treated in buffer (7.5 M guanidine- $\mathrm{HCl}, 0.1 \mathrm{M}$ Tris- $\mathrm{HCl}$, and $1 \mathrm{mM}$ EDTA) in the presence of $20 \mathrm{mM}$ DTT and incubated at $70^{\circ} \mathrm{C}$ for 15 min. Mass spectrometry data were acquired on an Agilent 6520 Accurate-Mass Q-TOF LC/MS System. (C) Binding affinity to FcyRllla measured by surface plasmon resonance on a Biacore X100 (GE Healthcare) using a single-cycle approach. (D) Comparisons of antibody-dependent cell-mediated cytotoxicity (ADCC) activity of 4Dm2m and 4Dm2m-F by using the Promega ADCC reporter assay. Jurkat T cells engineered to express human FcyRllla and luciferase, through which ADCC signals were monitored. 

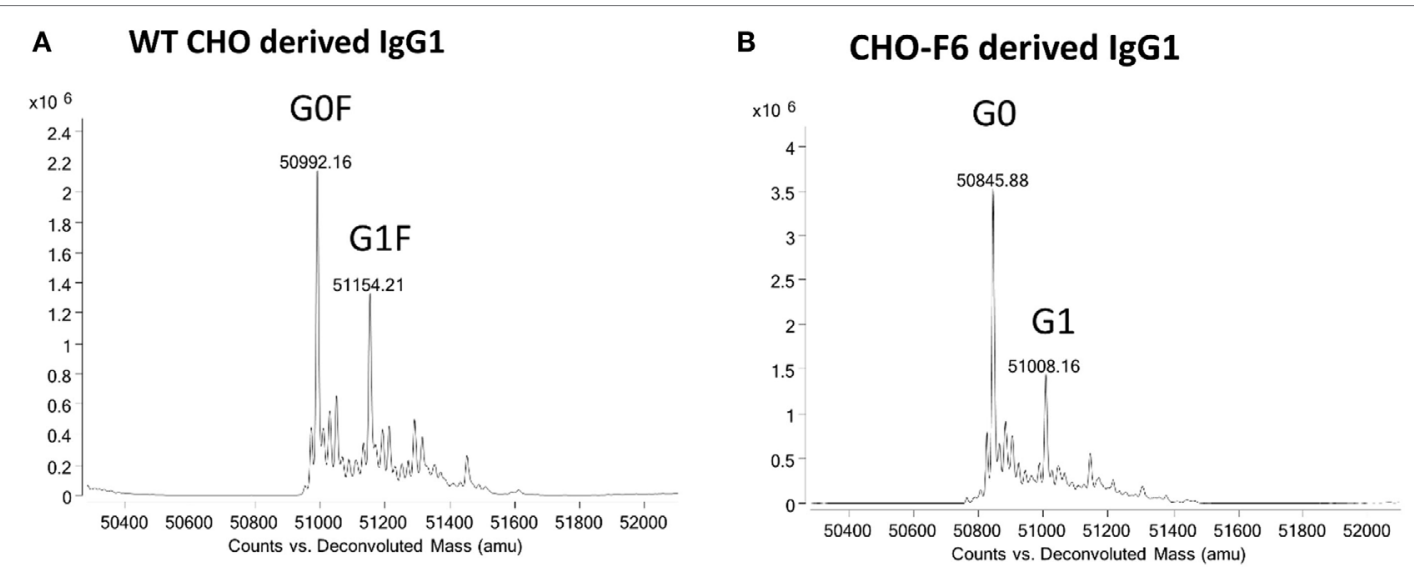

FIGURE 7 | Knockout of GDP-fucose transporter gene in $\mathrm{CHO}$ cell line to generate $\mathrm{CHO}$-F6 cell line for the production of afucosylated immunoglobulin Gs. (A) Deconvoluted mass spectra for heavy chain of m860 produced in the wide-type $\mathrm{CHO}$ cells (110). (B) Deconvoluted mass spectra for heavy chain of m860 produced in the $\mathrm{CHO}-\mathrm{F} 6$ cell line. M860 and m860-F were treated in buffer (7.5 M guanidine- $\mathrm{HCl}, 0.1 \mathrm{M}$ Tris- $\mathrm{HCl}$, and $1 \mathrm{mM}$ EDTA) in the presence of $20 \mathrm{mM}$ DTT and incubated at $70^{\circ} \mathrm{C}$ for $15 \mathrm{~min}$. Mass spectrometry data were acquired on an Agilent 6520 Accurate-Mass Q-TOF LC/MS System.

technology overexpresses $\beta$-1,4-GlcNAc transferase III (GnT III) to inhibit the downstream $\alpha-1,6$-fucosyltransferase processing leading to the bisecting GlcNAc glycoforms rather than fucosylation (108). This technology has been used to produce the FDA approved anti-CD20 obinutuzumab (Gazyva ${ }^{\circledR}$ ) (57). Co-overexpression of GnT III and $\alpha$-mannosidase II leads to further lower fucose content by introducing non-fucosylated hybrid-type glycans (109). Another approach to control the desired or unwanted glycoforms is either genetically inactivating or increasing glycosyltransferases activity directly responsible for transferring of single monosaccharides to glycan structures. For sialylation, overexpression of $\alpha$-2,3-sialyltransferase and $\beta$-1,4-galactosyltransferase elevates IgG sialylation and galactosylation (32). For fucosylation, genetically dampening FUT8 expression encoding $\alpha-1$, 6-fucosyltransferase significantly decreases or completely abolishes the terminal fucose (99). Small interfering RNA (siRNA) technique has been used to reduce $\alpha-1,6$-fucosyltransferase activity for production of partially defucosylated IgGs (59). Furthermore, double siRNA knockdown of FUT8 and GMD gene achieves completely afucosylated IgG (60). Alternatively, knockout of FUT8 gene by the disruption of the genomic locus via homologous recombination could result in $100 \%$ afucosylated IgGs (62). One such afucosylation platform is the Potelligent Technology from Kyowa Hakko Kirin company utilizing FUT8 KO CHO cell line to develop the anti-CCR4 mogamulizumab (Table 1, the first approved glycoengineered antibody) (61).

\section{"Humanization" of N-Glycosylation Pathway of Non-Mammalian Cells}

Some non-mammalian cell lines have been used to produce therapeutic antibodies due to the cost-effectiveness and/or decreased fucosylation (31). Glycoengineering of non-mammalian cells aims to humanize the immunogenic glycoforms by eliminating enzymes responsible for adding non-mammalian glycans and subsequently introducing the mammalian glycan processing enzymes. For example, knockout of the och or alg3 genes in yeasts and knockout of plant-specific $\beta$-1,2-xylosyltransferase $(\beta-1$, 2 -XylT) and $\alpha$-1,3-fucosyltransferase ( $\alpha$-1,3-FucT) genes achieve the elimination of the high mannose glycoforms and $\beta 1,2$-xylose and core $\alpha 1,3$-fucose. The mammalian glycan processing enzymes such as mannosidases I and II, GnT I and II, $\beta-1,4-$ GalT, and $\alpha$-2,6-SiaT are then used to introduce human IgG-like glycoforms (13). Examples include the production of the rituximab in Pichia pastoris (45), the anti-HIV mAb 2G12 in Nicotiana benthamiana (111), and the anti-Ebola ZMAPP antibody cocktail (lack of core fucose) in plant (48).

\section{Chemoenzymatic Glycoengineering}

Despite much progress in cell glycoengineering, it is still very challenging to produce IgGs with highly homogenous glycoforms in host cells. Consequently, the in vitro chemoenzymatic glycosylation remodeling provides an attractive alternative for the production of therapeutic mAbs with predefined and homogeneous glycoforms $(34,112)$. This method usually contains three steps: deglycosylation of IgG by an endo- $\beta$ - $N$-acetylglucosaminidase (ENGase, such as endoglycosidase S, EndoS), simultaneously leaving the innermost GlcNAc at N297; preparation of oxazoline derivatives of customized $\mathrm{N}$-linked glycan structures as sugars donors by chemical methods; transglycosylation of the glycan oxazoline donor to the innermost GlcNAc acceptor (113). The transglycosylation usually proceeds stereo-specifically under the catalysis of an ENGase, which was engineered to abolish the hydrolytic activity and improve substrate specificities (e.g., EndoS D233Q, EndoA N171A, EndoA E173Q, EndoMN175A, and EndoM N175Q) $(114,115)$. This chemoenzymatic approach has been successfully used to produce homogenous Fc glycoforms including non-fucosylated, fully sialylated and bisecting GlcNAc $(116,117)$. For example, rituximab was engineered from G0F, G1F, and G2F glycoforms to G2 and G2S2F glycoforms by EndoS-D233A and D233Q (114). Recently, the chemoenzymatic glycosylation remodeling was also elegantly used for site-specific conjugation of drugs onto antibodies (see below). 


\section{AGLYCOSYLATED FULL-LENGTH IgG AS A NOVEL THERAPEUTIC FORMAT}

In recent years, aglycosylated full-length IgGs have gained substantial attentions due to their novel features $(43,118)$. Although the absence of $\mathrm{N}$-glycans leads to the "closed" conformation of $\mathrm{Fc}$ and destabilization of $\mathrm{C}^{\prime} \mathrm{E}$ loop, the overall structures of aglycosylated IgG are similar to the glycosylated counterparts $(119,120)$. Thus, aglycosylated IgGs have almost identical antigen-binding affinity and $\mathrm{pH}$-dependent $\mathrm{FcRn}$ binding and hence PK to glycosylated IgGs (121), which endows aglycosylated mAbs applications in the cases not requiring or avoiding undesired effector functions such as receptor blocking, targeted delivery, and anti-inflammation (122). Aglycosylated mAbs can be either produced in prokaryotic hosts (E. coli) or in eukaryotic hosts by introducing mutations at the Fc N297 or by the chemoenzymatic methods such as EndoS and PNGase-F enzyme treatment (120). Compared with the glycosylated IgG, aglycosylated IgG is devoid of glycan heterogeneity, hence significantly simplifies the biomanufacturing process leading to faster development timelines and lower developmental cost. Besides, aglycosylated IgG may be more susceptible to engineering due to the higher flexibility of the Fc conferred by the lack of N-glycans (118). Aglycosylated Fc could be engineered to restore or even improve its binding to $\mathrm{Fc} \gamma \mathrm{Rs}$ compared with glycosylated counterparts, which potentially extends the applications of aglycosylated IgGs into the cases effector functions are needed. For example, aglycosylated IgG-Fc could be engineered to bind to FcyRIIa and FcyRIIb comparably with glycosylated IgG-Fc by introducing double mutations S298G/T299A (123). More importantly, the higher flexibility renders the aglycosylated Fc being relatively easily engineered to exhibit unique $F c \gamma R$ specificity and novel effector functions. Jung et al. have used high-throughput library screening to develop an aglycosylated trastuzumab variant with five mutations (S298G/T299A/ N390D/E382V/M428L) in Fc exhibiting >160-fold enhanced binding to FcyRIIa-R131 and 25-fold increased selectivity to FcyRIIa-R131 over FcRII $\gamma$ b compared with the wide-type trastuzumab (124). Aglycosylated IgGs have established a new way for immunotherapy. Currently, several aglycosylated antibodies are under clinical investigation for efficacy and safety (120).

\section{Fc N-GLYCAN SPECIFIC ADC}

Antibody-drug conjugates are IgGs conjugated with cytotoxic small molecules through chemical linkers. By specifically targeting cancer cells and selective delivery of highly cytotoxic drugs, ADCs fundamentally revolutionized the way of cancer immunotherapy and chemotherapy (125). Currently, four ADCs (Adcetris ${ }^{\circledR}, K^{2}$ adcyla ${ }^{\circledR}$, Besponsa ${ }^{\circledR}$, and Mylotarg ${ }^{\circledR}$ ) have been approved by FDA with more than 80 ADCs under clinical evaluations (126). The mode of action of ADCs involves antigenmediated endocytosis, followed by the release of drugs by either lysosomal degradation or hydrolytic/proteolytic cleavage (127). The methods for conjugating the small molecule drugs onto IgG represent one of the key technologies in ADC development. The conventional conjugation approaches involve random addition of drugs onto Lys or reduced Cys residues by amide coupling and maleimide alkylation chemistry, which leads to highly heterogeneous mixtures with different drug-antibody ratios and inconsistent yield (128). This heterogeneity negatively impacts the in vivo efficacy, stability, PK of ADCs (129). Thus, site-specific conjugation methods are highly pursued (130). Conjugation through IgG-Fc N-glycans represents one of the most widely used site-specific conjugation methods (131). Glycosite-specific conjugation proceeds with the introduction of a chemically active moiety onto the $\mathrm{Fc} \mathrm{N}$-glycans followed by reacting with payloads carrying another chemically active group. In this method, native IgG with heterogeneous $\mathrm{N}$-glycans is deglycosylated by a wild-type endoglycosidase followed by the transglycosylation of a chemical group capped homogenous $\mathrm{N}$-glycan substrate. The transglycosylation is catalyzed by an endoglycosynthase (a mutant of endoglycosidase) that lacks hydrolytic activity but possesses transglycosylation activity (132). Subsequently, the drug payload can be conjugated by biocompatible chemical reactions such as click chemistry and oximation. Boons et al. have reported the utilization of a sialyltransferase to attach an azido-tagged sialic acid moiety onto the galactosylated $\operatorname{IgG} \mathrm{N}$-glycan and conjugate the payload, doxorubicin on the azido group via the "click chemistry" (133). van Geel et al. reported a different method to produce ADC, which involved the endoglycosidase-mediated deglycosylation to obtain the Fuc- $\alpha-1,6$-GlcNAc disaccharide glycoform of IgG, followed by the addition of azido-capped UDP-galactose catalyzed by a mutant galactosyltransferase (134). Our group has exploited a galactosyltransferase mutant ( $\beta-1,4-$ Gal-T1-Y289L) to achieve glycosite-specific conjugation by transferring the keto-tagged or azido-tagged galactose onto the degalactosylated G0F glycoform of IgG. The final ADC products, m860-AF (Auristatin F) ADC and m276-PBD (pyrrolobenzodiazepine) ADC, were obtained through the keto oximation-mediated addition of AF and the "click chemistry"-mediated addition of PBD dimer onto m860 IgG1 and $\mathrm{m} 276$ IgG1, respectively (110, 135). The glycosite-specific conjugation strategies provide novel routes for the preparations of ADCs with better homogeneity and drug to antibody ratios.

\section{CONCLUSION AND PERSPECTIVES}

Unlike DNA and protein synthesis, antibody glycosylation synthesis is not directly template driven but is rather a result of networks of enzymatic reactions. Both host cells and the culture environment impact antibody glycosylation. Recombinant mAbs produced in host cells carry heterogenous Fc glycosylation, presumably with more than 400 possible glycoforms. Different glycoforms affect the in vivo efficacy, effector function, PK, stability, aggregation, safety, and immunogenicity of IgG. Among these, the impacts of $\mathrm{Fc} \mathrm{N}$-glycans on antibody effector function including ADCC and CDC are widely studied. IgG $\mathrm{N}$-glycans affect their ADCC and CDC activity by altering Fc conformations and modulating the non-covalent interactions between oligosaccharides and $\mathrm{C}_{\mathrm{H}} 2$ domains. While the terminal Gal enhances CDC activity, the core fucose significantly inhibits 
ADCC by sterically hindering the interactions between IgG-Fc and FcyRIIIa. Thus, the regulatory authorities require developers to keep glycoforms of mAbs consistent with limited heterogeneity, which has driven the development of multiple cell glycoengineering strategies to produce mAbs with desired glycoforms, especially without fucose. Although progress has been made, it is still challenging to consistently produce fully homogenously glycosylated antibodies by glycoengineered cell lines. The chemoenzymatic glycosylation remodeling offers revolutionized avenues to IgG with homogenous glycoforms. However, most current chemoenzymatic glycoengineering is still under lab-scale explorations, which is very challenging to scale up for industrial development. The chemoenzymatic glycoengineering approaches also provide novel routes for the productions of ADCs. On the other hand, the glyco-heterogeneity of mAbs could be bypassed by aglycosylated full-length IgGs. However, it remains to be seen for the outcomes of the clinical trials of aglycosylated antibodies in terms of the in vivo stability and immunogenicity. In the future, "omics" technologies and systems biology modeling hold promises to aid the glycoengineering for

\section{REFERENCES}

1. Elvin JG, Couston RG, van der Walle CF. Therapeutic antibodies: market considerations, disease targets and bioprocessing. Int JPharm (2013) 440:83-98. doi:10.1016/j.ijpharm.2011.12.039

2. Reichert JM. Antibodies to watch in 2017. MABs (2017) 9:167-81. doi:10.1080/19420862.2016.1269580

3. Niwa R, Satoh M. The current status and prospects of antibody engineering for therapeutic use: focus on glycoengineering technology. J Pharm Sci (2015) 104:930-41. doi:10.1002/jps.24316

4. Walsh G. Biopharmaceutical benchmarks 2014. Nat Biotechnol (2014) 32:992-1000. doi:10.1038/nbt.3040

5. Beck A, Wagner-Rousset E, Bussat MC, Lokteff M, Klinguer-Hamour C, Haeuw JF, et al. Trends in glycosylation, glycoanalysis and glycoengineering of therapeutic antibodies and Fc-fusion proteins. Curr Pharm Biotechnol (2008) 9:482-501. doi:10.2174/138920108786786411

6. Jefferis R. Glycosylation of recombinant antibody therapeutics. Biotechnol Prog (2005) 21:11-6. doi:10.1021/bp040016j

7. Jefferis R. Glycosylation as a strategy to improve antibody-based therapeutics. Nat Rev Drug Discov (2009) 8:226-34. doi:10.1038/nrd2804

8. Liu L. Pharmacokinetics of monoclonal antibodies and $\mathrm{Fc}$-fusion proteins. Protein cell (2017). doi:10.1007/s13238-017-0408-4

9. Liu L. Antibody glycosylation and its impact on the pharmacokinetics and pharmacodynamics of monoclonal antibodies and $\mathrm{Fc}$-fusion proteins. J Pharm Sci (2015) 104:1866-84. doi:10.1002/jps.24444

10. Liu H, Nowak C, Andrien B, Shao M, Ponniah G, Neill A. Impact of IgG Fc-oligosaccharides on recombinant monoclonal antibody structure, stability, safety, and efficacy. Biotechnol Prog (2017) 33(5):1173-81. doi:10.1002/ btpr.2498

11. Bournazos S, Wang TT, Dahan R, Maamary J, Ravetch JV. Signaling by antibodies: recent progress. Annu Rev Immunol (2017) 35:285-311. doi:10.1146/ annurev-immunol-051116-052433

12. Quast I, Peschke B, Lunemann JD. Regulation of antibody effector functions through IgG Fc N-glycosylation. Cell Mol Life Sci (2017) 74:837-47. doi:10.1007/s00018-016-2366-Z

13. Le NP, Bowden TA, Struwe WB, Crispin M. Immune recruitment or suppression by glycan engineering of endogenous and therapeutic antibodies. Biochim Biophys Acta(2016) 1860:1655-68.doi:10.1016/j.bbagen.2016.04.016

14. Raju TS. Terminal sugars of Fc glycans influence antibody effector functions of IgGs. Curr Opin Immunol (2008) 20:471-8. doi:10.1016/j.coi.2008.06.007

15. Subedi GP, Barb AW. The structural role of antibody N-glycosylation in receptorinteractions. Structure(2015)23:1573-83.doi:10.1016/j.str.2015.06.015 developing next-generation mAbs with homogenous glycoforms and improved therapeutic efficacy.

\section{AUTHOR CONTRIBUTIONS}

DD conceived the topic; WL wrote the manuscript; ZZ, YF, and WC revised the manuscript.

\section{FUNDING}

The authors thank the Intramural AIDS Targeted Antiviral Program (IATAP) of the National Institutes of Health (NIH), the Intramural Research Program of the NIH, National Cancer Institute (NCI), Center for Cancer Research, the U.S.-China Program for Biomedical Research Cooperation, and the U.S.China Program for Research toward a Cure for HIV/AIDS. The content of this publication does not necessarily reflect the views or policies of the Department of Health and Human Services nor does the mention of trade names, commercial products, or organizations imply endorsement by the U.S. Government.

16. Brader ML, Estey T, Bai S, Alston RW, Lucas KK, Lantz S, et al. Examination of thermal unfolding and aggregation profiles of a series of developable therapeutic monoclonal antibodies. Mol Pharm (2015) 12:1005-17. doi:10.1021/ mp400666b

17. Mimura Y, Church S, Ghirlando R, Ashton PR, Dong S, Goodall M, et al. The influence of glycosylation on the thermal stability and effector function expression of human IgG1-Fc: properties of a series of truncated glycoforms. Mol Immunol (2000) 37:697-706. doi:10.1016/S0161-5890(00)00105-X

18. Feige MJ, Walter S, Buchner J. Folding mechanism of the $\mathrm{CH} 2$ antibody domain. J Mol Biol (2004) 344:107-18. doi:10.1016/j.jmb.2004.09.033

19. Zheng K, Bantog C, Bayer R. The impact of glycosylation on monoclonal antibody conformation and stability. MABs (2011) 3:568-76. doi:10.4161/ mabs.3.6.17922

20. Krapp S, Mimura Y, Jefferis R, Huber R, Sondermann P. Structural analysis of human IgG-Fc glycoforms reveals a correlation between glycosylation and structural integrity. J Mol Biol (2003) 325:979-89. doi:10.1016/ S0022-2836(02)01250-0

21. Tao MH, Morrison SL. Studies of aglycosylated chimeric mouse-human IgG. Role of carbohydrate in the structure and effector functions mediated by the human IgG constant region. J Immunol (1989) 143:2595-601.

22. Raju TS, Scallon B. Fc glycans terminated with $\mathrm{N}$-acetylglucosamine residues increase antibody resistance to papain. Biotechnol Prog (2007) 23:964-71. doi:10.1021/bp070118k

23. Raju TS, Scallon BJ. Glycosylation in the Fc domain of IgG increases resistance to proteolytic cleavage by papain. Biochem Biophys Res Commun (2006) 341:797-803. doi:10.1016/j.bbrc.2006.01.030

24. Raju TS, Briggs JB, Chamow SM, Winkler ME, Jones AJ. Glycoengineering of therapeutic glycoproteins: in vitro galactosylation and sialylation of glycoproteins with terminal $\mathrm{N}$-acetylglucosamine and galactose residues. Biochemistry (2001) 40:8868-76. doi:10.1021/bi010475i

25. Jones AJ, Papac DI, Chin EH, Keck R, Baughman SA, Lin YS, et al. Selective clearance of glycoforms of a complex glycoprotein pharmaceutical caused by terminal $\mathrm{N}$-acetylglucosamine is similar in humans and cynomolgus monkeys. Glycobiology (2007) 17:529-40. doi:10.1093/glycob/cwm017

26. Goetze AM, Liu YD, Zhang Z, Shah B, Lee E, Bondarenko PV, et al. Highmannose glycans on the $F_{C}$ region of therapeutic IgG antibodies increase serum clearance in humans. Glycobiology (2011) 21:949-59. doi:10.1093/ glycob/cwr027

27. Wright A, Sato Y, Okada T, Chang K, Endo T, Morrison S. In vivo trafficking and catabolism of IgG1 antibodies with Fc associated carbohydrates of differing structure. Glycobiology (2000) 10:1347-55. doi:10.1093/glycob/ 10.12.1347 
28. Ghaderi D, Taylor RE, Padler-Karavani V, Diaz S, Varki A. Implications of the presence of $\mathrm{N}$-glycolylneuraminic acid in recombinant therapeutic glycoproteins. Nat Biotechnol (2010) 28:863-7. doi:10.1038/nbt.1651

29. Chung CH, Mirakhur B, Chan E, Le QT, Berlin J, Morse M, et al. Cetuximabinduced anaphylaxis and IgE specific for galactose-alpha-1,3-galactose. N Engl J Med (2008) 358:1109-17. doi:10.1056/NEJMoa074943

30. Reusch D, Tejada ML. Fc glycans of therapeutic antibodies as critical quality attributes. Glycobiology (2015) 25:1325-34. doi:10.1093/glycob/cwv065

31. Dicker M, Strasser R. Using glyco-engineering to produce therapeutic proteins. Expert Opin Biol Ther (2015) 15:1501-16. doi:10.1517/14712598. 2015.1069271

32. Costa AR, Rodrigues ME, Henriques M, Oliveira R, Azeredo J. Glycosylation: impact, control and improvement during therapeutic protein production. Crit Rev Biotechnol (2014) 34:281-99. doi:10.3109/07388551.2013.793649

33. Jefferis R. Isotype and glycoform selection for antibody therapeutics. Arch Biochem Biophys (2012) 526:159-66. doi:10.1016/j.abb.2012.03.021

34. Mimura Y, Katoh T, Saldova R, O'Flaherty R, Izumi T, Mimura-Kimura Y, et al. Glycosylation engineering of therapeutic IgG antibodies: challenges for the safety, functionality and efficacy. Protein Cell (2017). doi:10.1007/ s13238-017-0433-3

35. Hale G, Rebello P, Al Bakir I, Bolam E, Wiczling P, Jusko WJ, et al. Pharmacokinetics and antibody responses to the CD3 antibody otelixizumab used in the treatment of type 1 diabetes. J Clin Pharmacol (2010) 50:1238-48. doi:10.1177/0091270009356299

36. Ng CM, Stefanich E, Anand BS, Fielder PJ, Vaickus L. Pharmacokinetics/ pharmacodynamics of nondepleting anti-CD4 monoclonal antibody (TRX1) in healthy human volunteers. Pharm Res (2006) 23:95-103. doi:10.1007/s11095-005-8814-3

37. Ishida $\mathrm{T}$, Joh $\mathrm{T}$, Uike $\mathrm{N}$, Yamamoto $\mathrm{K}$, Utsunomiya $\mathrm{A}$, Yoshida $\mathrm{S}$, et al. Defucosylated anti-CCR4 monoclonal antibody (KW-0761) for relapsed adult T-cell leukemia-lymphoma: a multicenter phase II study. J Clin Oncol (2012) 30:837-42. doi:10.1200/JCO.2011.37.3472

38. Duvic M, Pinter-Brown L, Foss FM, Sokol L, Jorgensen J, Spitalny GL, et al. Results of a phase $1 / 2$ study for KW-0761, a monoclonal antibody directed against CC chemokine receptor type 4 (CCR4), in CTCL patients. Blood (2010) 116:962-962.

39. Camacho LH, Joyce R, Brown JR, Chanan-Khan A, Amrein PC, Assad A, et al. A phase 1, open-label, multi-center, multiple-dose, dose-escalation study of MDX-1342 in patients with CD19-positive refractory/relapsed chronic lymphocytic leukemia. Blood (2009) 114:3425-3425.

40. Goede V, Fischer K, Busch R, Engelke A, Eichhorst B, Wendtner CM, et al. Obinutuzumab plus chlorambucil in patients with CLL and coexisting conditions. N Engl J Med (2014) 370:1101-10. doi:10.1056/NEJMoa1313984

41. Yu X, Marshall MJE, Cragg MS, Crispin M. Improving antibody-based cancer therapeutics through glycan engineering. BioDrugs (2017) 31:151-66. doi:10.1007/s40259-017-0223-8

42. Paz-Ares LG, Gomez-Roca C, Delord JP, Cervantes A, Markman B, Corral J, et al. Phase I pharmacokinetic and pharmacodynamic dose-escalation study of RG7160 (GA201), the first glycoengineered monoclonal antibody against the epidermal growth factor receptor, in patients with advanced solid tumors. J Clin Oncol (2011) 29:3783-90. doi:10.1200/JCO.2011.34.8888

43. Hristodorov D, Fischer R, Linden L. With or without sugar? (A)glycosylation of therapeutic antibodies. Mol Biotechnol (2013) 54:1056-68. doi:10.1007/ s12033-012-9612-x

44. Peschke B, Keller CW, Weber P, Quast I, Lunemann JD. Fc-galactosylation of human immunoglobulin gamma isotypes improves $\mathrm{C} 1 \mathrm{q}$ binding and enhances complement-dependent cytotoxicity. Front Immunol (2017) 8:646. doi:10.3389/fimmu.2017.00646

45. Li H, Sethuraman N, Stadheim TA, Zha D, Prinz B, Ballew N, et al. Optimization of humanized IgGs in glycoengineered Pichia pastoris. Nat Biotechnol (2006) 24:210-5. doi:10.1038/nbt1178

46. Liu B, Gong X, Chang S, Yang Y, Song M, Duan D, et al. Disruption of the $\mathrm{OCH} 1$ and $\mathrm{MNN} 1$ genes decrease N-glycosylation on glycoprotein expressed in Kluyveromyces lactis. J Biotechnol (2009) 143:95-102. doi:10.1016/j. jbiotec.2009.06.016

47. Davidson RC, Nett JH, Renfer E, Li H, Stadheim TA, Miller BJ, et al. Functional analysis of the ALG3 gene encoding the Dol-P-Man: Man5GlcNAc2-PP-Dol mannosyltransferase enzyme of P. pastoris. Glycobiology (2004) 14:399-407. doi:10.1093/glycob/cwh023
48. Castilho A, Bohorova N, Grass J, Bohorov O, Zeitlin L, Whaley K, et al. Rapid high yield production of different glycoforms of Ebola virus monoclonal antibody. PLoS One (2011) 6:e26040. doi:10.1371/journal.pone.0026040

49. Davey RT Jr, Dodd L, Proschan MA, Neaton J, Neuhaus Nordwall J, Koopmeiners JS, et al. A randomized, controlled trial of ZMapp for Ebola virus infection. N Eng J Med (2016) 375:1448-56. doi:10.1056/NEJMoa1604330

50. Urbain R, Teillaud JL, Prost JF. [EMABling antibodies: from feto-maternal allo-immunisation prophylaxis to chronic lymphocytic leukaemia therapy]. Med Sci (Paris) (2009) 25:1141-4. doi:10.1051/medsci/200925121141

51. Shields RL, Lai J, Keck R, O’Connell LY, Hong K, Meng YG, et al. Lack of fucose on human IgG1 N-linked oligosaccharide improves binding to human Fcgamma RIII and antibody-dependent cellular toxicity. J Biol Chem (2002) 277:26733-40. doi:10.1074/jbc.M202069200

52. Gardai SJ, Epp A, Linares G, Westendorf L, Sutherland MK, Neff-LaFord H, et al. A sugar engineered non-fucosylated anti-CD40 antibody, SEA-CD40, with enhanced immune stimulatory activity alone and in combination with immune checkpoint inhibitors. J Clin Oncol (2015) 33:3074-3074. doi:10.1200/jco.2015.33.15_suppl.3074

53. Kanda Y, Imai-Nishiya H, Kuni-Kamochi R, Mori K, Inoue M, KitajimaMiyama K, et al. Establishment of a GDP-mannose 4,6-dehydratase (GMD) knockout host cell line: a new strategy for generating completely non-fucosylated recombinant therapeutics. J Biotechnol (2007) 130:300-10. doi:10.1016/j.jbiotec.2007.04.025

54. von Horsten HH, Ogorek C, Blanchard V, Demmler C, Giese C, Winkler K, et al. Production of non-fucosylated antibodies by co-expression of heterologous GDP-6-deoxy-D-lyxo-4-hexulose reductase. Glycobiology (2010) 20:1607-18. doi:10.1093/glycob/cwq109

55. Bardhi A, Wu Y, Chen W, Zhu Z, Zheng JH, Wong H, et al. Potent in vivo NK cell-mediated elimination of HIV-1-infected cells mobilized by a gp120-bispecific and hexavalent broadly neutralizing fusion protein. $J$ Virol (2017) 91(20):e937-917. doi:10.1128/JVI.00937-17

56. Chen W, Bardhi A, Feng Y, Wang Y, Qi Q, Li W, et al. Improving the CH1-CK heterodimerization and pharmacokinetics of $4 \mathrm{Dm} 2 \mathrm{~m}$, a novel potent CD4antibody fusion protein against HIV-1. MABs (2016) 8:761-74. doi:10.1080/ 19420862.2016.1160180

57. Robak T, Robak E. New anti-CD20 monoclonal antibodies for the treatment of B-cell lymphoid malignancies. BioDrugs (2011) 25:13-25. doi:10.2165/11539590-000000000-00000

58. Mirschberger C, Schiller CB, Schraml M, Dimoudis N, Friess T, Gerdes CA, et al. RG7116, a therapeutic antibody that binds the inactive HER3 receptor and is optimized for immune effector activation. Cancer Res (2013) 73:5183-94. doi:10.1158/0008-5472.CAN-13-0099

59. Mori K, Kuni-Kamochi R, Yamane-Ohnuki N, Wakitani M, Yamano K, Imai $\mathrm{H}$, et al. Engineering Chinese hamster ovary cells to maximize effector function of produced antibodies using FUT8 siRNA. Biotechnol Bioeng (2004) 88:901-8. doi:10.1002/bit.20326

60. Imai-Nishiya H, Mori K, Inoue M, Wakitani M, Iida S, Shitara K, et al. Double knockdown of alpha1,6-fucosyltransferase (FUT8) and GDP-mannose 4,6-dehydratase (GMD) in antibody-producing cells: a new strategy for generating fully non-fucosylated therapeutic antibodies with enhanced ADCC. BMC Biotechnol (2007) 7:84. doi:10.1186/1472-6750-7-84

61. Matsushita T. Engineered therapeutic antibodies with enhanced effector functions: clinical application of the Potelligent(R) Technology. Korean J Hematol (2011) 46:148-50. doi:10.5045/kjh.2011.46.3.148

62. Yamane-Ohnuki N, Kinoshita S, Inoue-Urakubo M, Kusunoki M, Iida S, Nakano R, et al. Establishment of FUT8 knockout Chinese hamster ovary cells: an ideal host cell line for producing completely defucosylated antibodies with enhanced antibody-dependent cellular cytotoxicity. Biotechnol Bioeng (2004) 87:614-22. doi:10.1002/bit.20151

63. Chen W, Feng Y, Prabakaran P, Ying T, Wang Y, Sun J, et al. Exceptionally potent and broadly cross-reactive, bispecific multivalent HIV-1 inhibitors based on single human CD4 and antibody domains. J Virol (2014) 88: 1125-39. doi:10.1128/JVI.02566-13

64. Zhang P, Woen S, Wang T, Liau B, Zhao S, Chen C, et al. Challenges of glycosylation analysis and control: an integrated approach to producing optimal and consistent therapeutic drugs. Drug Discov Today (2016) 21:740-65. doi:10.1016/j.drudis.2016.01.006

65. Nagae M, Yamaguchi Y. Function and 3D structure of the N-glycans on glycoproteins. Int J Mol Sci (2012) 13:8398-429. doi:10.3390/ijms13078398 
66. Wormald MR, Rudd PM, Harvey DJ, Chang SC, Scragg IG, Dwek RA. Variations in oligosaccharide-protein interactions in immunoglobulin $G$ determine the site-specific glycosylation profiles and modulate the dynamic motion of the Fc oligosaccharides. Biochemistry (1997) 36:1370-80. doi:10.1021/bi9621472

67. Jefferis R. Recombinant antibody therapeutics: the impact of glycosylation on mechanisms of action. Trends Pharmacol Sci (2009) 30:356-62. doi:10.1016/j. tips.2009.04.007

68. Zauner G, Selman MHJ, Bondt A, Rombouts Y, Blank D, Deelder AM, et al. Glycoproteomic analysis of antibodies. Mol Cell Proteomics (2013) 12:856-65. doi:10.1074/mcp.R112.026005

69. Wuhrer M, Stam JC, van de Geijn FE, Koeleman CA, Verrips CT, Dolhain RJ, et al. Glycosylation profiling of immunoglobulin G (IgG) subclasses from human serum. Proteomics (2007) 7:4070-81. doi:10.1002/ pmic. 200700289

70. Raju TS, Briggs JB, Borge SM, Jones AJ. Species-specific variation in glycosylation of IgG: evidence for the species-specific sialylation and branch-specific galactosylation and importance for engineering recombinant glycoprotein therapeutics. Glycobiology (2000) 10:477-86. doi:10.1093/glycob/ 10.5.477

71. Butters TD. Control in the N-linked glycoprotein biosynthesis pathway. Chem Biol (2002) 9:1266-8. doi:10.1016/S1074-5521(02)00290-9

72. Brooks SA. Appropriate glycosylation of recombinant proteins for human use: implications of choice of expression system. Mol Biotechnol (2004) 28:241-55. doi:10.1385/MB:28:3:241

73. Girardi E, Holdom MD, Davies AM, Sutton BJ, Beavil AJ. The crystal structure of rabbit IgG-Fc. Biochem J (2009) 417:77-83. doi:10.1042/ BJ20081355

74. Matsumiya S, Yamaguchi Y, Saito J, Nagano M, Sasakawa H, Otaki S, et al. Structural comparison of fucosylated and nonfucosylated Fc fragments of human immunoglobulin G1. J Mol Biol (2007) 368:767-79. doi:10.1016/j. jmb.2007.02.034

75. Kiyoshi M, Tsumoto K, Ishii-Watabe A, Caaveiro JMM. Glycosylation of IgG-Fc: a molecular perspective. Int Immunol (2017) 29(7):311-7. doi:10.1093/intimm/dxx038

76. Chiang AW, Li S, Spahn PN, Richelle A, Kuo CC, Samoudi M, et al. Modulating carbohydrate-protein interactions through glycoengineering of monoclonal antibodies to impact cancer physiology. Curr Opin Struct Biol (2016) 40:104-11. doi:10.1016/j.sbi.2016.08.008

77. Raju TS, Lang SE. Diversity in structure and functions of antibody sialylation in the Fc. Curr Opin Biotechnol (2014) 30:147-52. doi:10.1016/j. copbio.2014.06.014

78. Bologna L, Gotti E, Manganini M, Rambaldi A, Intermesoli T, Introna M, et al. Mechanism of action of type II, glycoengineered, anti-CD20 monoclonal antibody GA101 in B-chronic lymphocytic leukemia whole blood assays in comparison with rituximab and alemtuzumab. J Immunol (2011) 186:3762-9. doi:10.4049/jimmunol.1000303

79. Ferrara C, Grau S, Jager C, Sondermann P, Brunker P, Waldhauer I, et al. Unique carbohydrate-carbohydrate interactions are required for high affinity binding between FcgammaRIII and antibodies lacking core fucose. Proc Natl Acad Sci U S A (2011) 108:12669-74. doi:10.1073/pnas.1108455108

80. Mizushima T, Yagi H, Takemoto E, Shibata-Koyama M, Isoda Y, Iida S, et al. Structural basis for improved efficacy of therapeutic antibodies on defucosylation of their Fc glycans. Genes Cells (2011) 16:1071-80. doi:10.1111/j.1365-2443.2011.01552.x

81. Iida S, Misaka H, Inoue M, Shibata M, Nakano R, Yamane-Ohnuki N, et al. Nonfucosylated therapeutic IgG1 antibody can evade the inhibitory effect of serum immunoglobulin G on antibody-dependent cellular cytotoxicity through its high binding to FcgammaRIIIa. Clin Cancer Res (2006) 12:2879-87. doi:10.1158/1078-0432.CCR-05-2619

82. Iida S, Kuni-Kamochi R, Mori K, Misaka H, Inoue M, Okazaki A, et al. Two mechanisms of the enhanced antibody-dependent cellular cytotoxicity (ADCC) efficacy of non-fucosylated therapeutic antibodies in human blood. BMC Cancer (2009) 9:58. doi:10.1186/1471-2407-9-58

83. Niwa R, Hatanaka S, Shoji-Hosaka E, Sakurada M, Kobayashi Y, Uehara A, et al. Enhancement of the antibody-dependent cellular cytotoxicity of low-fucose IgG1 is independent of FcgammaRIIIa functional polymorphism. Clin Cancer Res (2004) 10:6248-55. doi:10.1158/1078-0432. CCR-04-0850
84. Weng W-K, Levy R. Two immunoglobulin G fragment C receptor polymorphisms independently predict response to rituximab in patients with follicular lymphoma. J Clin Oncol (2003) 21:3940-7. doi:10.1200/JCO.2003.05.013

85. Shibata-Koyama M, Iida S, Misaka H, Mori K, Yano K, Shitara K, et al. Nonfucosylated rituximab potentiates human neutrophil phagocytosis through its high binding for FcgammaRIIIb and MHC class II expression on the phagocytotic neutrophils. Exp Hematol (2009) 37:309-21. doi:10.1016/j. exphem.2008.11.006

86. Hodoniczky J, Zheng YZ, James DC. Control of recombinant monoclonal antibody effector functions by Fc N-glycan remodeling in vitro. Biotechnol Prog (2005) 21:1644-52. doi:10.1021/bp050228w

87. Starovasnik MA, Braisted AC, Wells JA. Structural mimicry of a native protein by a minimized binding domain. Proc Natl Acad Sci U S A (1997) 94:10080-5. doi:10.1073/pnas.94.19.10080

88. Sauer-Eriksson AE, Kleywegt GJ, Uhlen M, Jones TA. Crystal structure of the C2 fragment of streptococcal protein G in complex with the Fc domain of human IgG. Structure (1995) 3:265-78. doi:10.1016/S0969-2126(01)00157-5

89. Ghirlando R, Lund J, Goodall M, Jefferis R. Glycosylation of human IgG-Fc: influences on structure revealed by differential scanning micro-calorimetry. Immunol Lett (1999) 68:47-52. doi:10.1016/S0165-2478(99)00029-2

90. Raju TS, Davidson EA. Role of sialic acid on the viscosity of canine tracheal mucin glycoprotein. Biochem Biophys Res Commun (1994) 205:402-9. doi:10.1006/bbrc.1994.2679

91. Crispin M, Yu X, Bowden TA. Crystal structure of sialylated IgG Fc: implications for the mechanism of intravenous immunoglobulin therapy. Proc Natl Acad Sci U S A (2013) 110:E3544-6. doi:10.1073/pnas.1310657110

92. Fang J, Richardson J, Du Z, Zhang Z. Effect of Fc-Glycan structure on the conformational stability of IgG revealed by hydrogen/deuterium exchange and limited proteolysis. Biochemistry (2016) 55:860-8. doi:10.1021/acs. biochem. 5 b01323

93. Scallon BJ, Tam SH, McCarthy SG, Cai AN, Raju TS. Higher levels of sialylated Fc glycans in immunoglobulin $G$ molecules can adversely impact functionality. Mol Immunol (2007) 44:1524-34. doi:10.1016/j.molimm.2006.09.005

94. Sondermann P, Kaiser J, Jacob U. Molecular basis for immune complex recognition: a comparison of FC-receptor structures. J Mol Biol (2001) 309:737-49. doi:10.1006/jmbi.2001.4670

95. Kaneko Y, Nimmerjahn F, Ravetch JV. Anti-inflammatory activity of immunoglobulin G resulting from Fc sialylation. Science (2006) 313:670-3. doi:10.1126/science.1129594

96. Anthony RM, Nimmerjahn F, Ashline DJ, Reinhold VN, Paulson JC, Ravetch JV. Recapitulation of IVIG anti-inflammatory activity with a recombinant IgG Fc. Science (2008) 320:373-6. doi:10.1126/science.1154315

97. Anthony RM, Ravetch JV. A novel role for the IgG Fc glycan: the antiinflammatory activity of sialylated IgG Fcs. JClin Immunol (2010) 30 (Suppl 1):S9-14. doi:10.1007/s10875-010-9405-6

98. Anthony RM, Kobayashi T, Wermeling F, Ravetch JV. Intravenous gammaglobulin suppresses inflammation through a novel $\mathrm{T}(\mathrm{H}) 2$ pathway. Nature (2011) 475:110-3. doi:10.1038/nature10134

99. Yamane-Ohnuki N, Satoh M. Production of therapeutic antibodies with controlled fucosylation. MABs (2009) 1:230-6. doi:10.4161/mabs.1.3.8328

100. Crowell CK, Grampp GE, Rogers GN, Miller J, Scheinman RI. Amino acid and manganese supplementation modulates the glycosylation state of erythropoietin in a CHO culture system. Biotechnol Bioeng (2007) 96:538-49. doi:10.1002/bit.21141

101. Patel TP, Parekh RB, Moellering BJ, Prior CP. Different culture methods lead to differences in glycosylation of a murine IgG monoclonal antibody. Biochem J (1992) 285(Pt 3):839-45. doi:10.1042/bj2850839

102. Okeley NM, Alley SC, Anderson ME, Boursalian TE, Burke PJ, Emmerton KM, et al. Development of orally active inhibitors of protein and cellular fucosylation. Proc Natl Acad Sci U S A (2013) 110:5404-9. doi:10.1073/pnas.1222263110

103. Powell LD. Inhibition of N-linked glycosylation. Curr Protoc Immunol. (2001) 9:8.14-1-9. doi:10.1002/0471142735.im0814s09

104. Sullivan FX, Kumar R, Kriz R, Stahl M, Xu GY, Rouse J, et al. Molecular cloning of human GDP-mannose 4,6-dehydratase and reconstitution of GDP-fucose biosynthesis in vitro. J Biol Chem (1998) 273:8193-202. doi:10.1074/jbc.273.14.8193

105. King JD, Poon KKH, Webb NA, Anderson EM, McNally DJ, Brisson JR, et al. The structural basis for catalytic function of GMD and RMD, two closely 
related enzymes from the GDP-D-rhamnose biosynthesis pathway. FEBS $J$ (2009) 276:2686-700. doi:10.1111/j.1742-4658.2009.06993.x

106. Son YD, Jeong YT, Park SY, Kim JH. Enhanced sialylation of recombinant human erythropoietin in Chinese hamster ovary cells by combinatorial engineering of selected genes. Glycobiology (2011) 21:1019-28. doi:10.1093/ glycob/cwr034

107. Chan KF, Shahreel W, Wan C, Teo G, Hayati N, Tay SJ, et al. Inactivation of

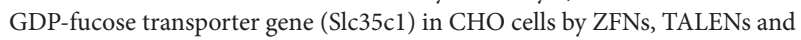
CRISPR-Cas9 for production of fucose-free antibodies. Biotechnol J (2016) 11:399-414. doi:10.1002/biot.201500331

108. Evans JB, Syed BA. From the analyst's couch: next-generation antibodies. Nat Rev Drug Discov (2014) 13:413-4. doi:10.1038/nrd4255

109. Ferrara C, Brunker P, Suter T, Moser S, Puntener U, Umana P. Modulation of therapeutic antibody effector functions by glycosylation engineering: influence of Golgi enzyme localization domain and co-expression of heterologous beta1, 4-N-acetylglucosaminyltransferase III and Golgi alpha-mannosidase II. Biotechnol Bioeng (2006) 93:851-61. doi:10.1002/bit.20777

110. Zhu Z, Ramakrishnan B, Li J, Wang Y, Feng Y, Prabakaran P, et al. Site-specific antibody-drug conjugation through an engineered glycotransferase and a chemically reactive sugar. MABs (2014) 6:1190-200. doi:10.4161/mabs.29889

111. Strasser R, Stadlmann J, Schahs M, Stiegler G, Quendler H, Mach L, et al. Generation of glyco-engineered Nicotiana benthamiana for the production of monoclonal antibodies with a homogeneous human-like N-glycan structure. Plant Biotechnol J (2008) 6:392-402. doi:10.1111/j.1467-7652.2008.00330.x

112. Rich JR, Withers SG. Emerging methods for the production of homogeneous human glycoproteins. Nat Chem Biol (2009) 5:206-15. doi:10.1038/ nchembio. 148

113. Wang LX, Lomino JV. Emerging technologies for making glycan-defined glycoproteins. ACS Chem Biol (2012) 7:110-22. doi:10.1021/cb200429n

114. Huang W, Giddens J, Fan SQ, Toonstra C, Wang LX. Chemoenzymatic glycoengineering of intact IgG antibodies for gain of functions. J Am Chem Soc (2012) 134:12308-18. doi:10.1021/ja3051266

115. Umekawa M, Huang W, Li B, Fujita K, Ashida H, Wang LX, et al. Mutants of Mucor hiemalis endo-beta-N-acetylglucosaminidase show enhanced transglycosylation and glycosynthase-like activities. JBiol Chem (2008) 283:4469-79. doi:10.1074/jbc.M707137200

116. Parsons TB, Struwe WB, Gault J, Yamamoto K, Taylor TA, Raj R, et al. Optimal synthetic glycosylation of a therapeutic antibody. Angew Chem Int Ed Engl (2016) 55:2361-7. doi:10.1002/anie.201508723

117. Huang W, Li C, Li B, Umekawa M, Yamamoto K, Zhang X, et al. Glycosynthases enable a highly efficient chemoenzymatic synthesis of N-glycoproteins carrying intact natural N-glycans. JAm Chem Soc (2009) 131:2214-23. doi:10.1021/ja8074677

118. Jung ST, Kang TH, Kelton W, Georgiou G. Bypassing glycosylation: engineering aglycosylated full-length IgG antibodies for human therapy. Curr Opin Biotechnol (2011) 22:858-67. doi:10.1016/j.copbio.2011.03.002

119. Borrok MJ, Jung ST, Kang TH, Monzingo AF, Georgiou G. Revisiting the role of glycosylation in the structure of human IgG Fc. ACS Chem Biol (2012) 7:1596-602. doi:10.1021/cb300130k

120. Ju MS, Jung ST. Aglycosylated full-length IgG antibodies: steps toward next-generation immunotherapeutics. Curr Opin Biotechnol (2014) 30:128-39. doi:10.1016/j.copbio.2014.06.013

121. Jung ST, Reddy ST, Kang TH, Borrok MJ, Sandlie I, Tucker PW, et al. Aglycosylated IgG variants expressed in bacteria that selectively bind FcgammaRI potentiate tumor cell killing by monocyte-dendritic cells. Proc Natl Acad Sci U S A (2010) 107:604-9. doi:10.1073/pnas.0908590107
122. Labrijn AF, Aalberse RC, Schuurman J. When binding is enough: nonactivating antibody formats. Curr Opin Immunol (2008) 20:479-85. doi:10.1016/j. coi.2008.05.010

123. Sazinsky SL, Ott RG, Silver NW, Tidor B, Ravetch JV, Wittrup KD. Aglycosylated immunoglobulin G1 variants productively engage activating Fc receptors. Proc Natl Acad Sci U S A (2008) 105:20167-72. doi:10.1073/ pnas.0809257105

124. Jung ST, Kelton W, Kang TH, Ng DT, Andersen JT, Sandlie I, et al. Effective phagocytosis of low Her2 tumor cell lines with engineered, aglycosylated IgG displaying high FcgammaRIIa affinity and selectivity. ACS Chem Biol (2013) 8:368-75. doi:10.1021/cb300455f

125. Thomas A, Teicher BA, Hassan R. Antibody-drug conjugates for cancer therapy. Lancet Oncol (2016) 17:e254-62. doi:10.1016/S1470-2045(16)30030-4

126. Tsuchikama K, An Z. Antibody-drug conjugates: recent advances in conjugation and linker chemistries. Protein Cell (2016). doi:10.1007/ s13238-016-0323-0

127. Teicher BA. Antibody drug conjugates. Curr Opin Oncol (2014) 26:476-83. doi:10.1097/CCO.0000000000000108

128. Feng Y, Zhu Z, Chen W, Prabakaran P, Lin K, Dimitrov DS. Conjugates of small molecule drugs with antibodies and other proteins. Biomedicines (2014) 2:1-13. doi:10.3390/biomedicines2010001

129. Li W, Prabakaran P, Chen W, Zhu Z, Feng Y, Dimitrov DS. Antibody aggregation: insights from sequence and structure. Antibodies (2016) 5:19. doi:10.3390/antib5030019

130. Panowski S, Bhakta S, Raab H, Polakis P, Junutula JR. Site-specific antibody drug conjugates for cancer therapy. MABs (2014) 6:34-45. doi:10.4161/ mabs. 27022

131. Vogel CW. Preparation of immunoconjugates using antibody oligosaccharide moieties.MethodsMolBiol(2004)283:87-108.doi:10.1385/1-59259-813-7:087

132. Tang F, Wang L-X, Huang W. Chemoenzymatic synthesis of glycoengineered IgG antibodies and glycosite-specific antibody-drug conjugates. Nat Protoc (2017) 12:1702-21. doi:10.1038/nprot.2017.058

133. Li X, Fang T, Boons GJ. Preparation of well-defined antibody-drug conjugates through glycan remodeling and strain-promoted azide-alkyne cycloadditions. Angew Chem Int Ed Engl (2014) 53:7179-82. doi:10.1002/ anie. 201402606

134. van Geel R, Wijdeven MA, Heesbeen R, Verkade JMM, Wasiel AA, van Berkel SS, et al. Chemoenzymatic conjugation of toxic payloads to the globally conserved $\mathrm{N}$-glycan of native mAbs provides homogeneous and highly efficacious antibody-drug conjugates. Bioconjug Chem (2015) 26:2233-42. doi:10.1021/acs.bioconjchem.5b00224

135. Seaman S, Zhu Z, Saha S, Zhang XM, Yang MY, Hilton MB, et al. Eradication of tumors through simultaneous ablation of CD276/B7-H3-positive tumor cells and tumor vasculature. Cancer Cell (2017) 31:501-515.e8. doi:10.1016/j. ccell.2017.03.005

Conflict of Interest Statement: The authors declare that the research was conducted in the absence of any commercial or financial relationships that could be construed as a potential conflict of interest.

Copyright $\odot 2017 \mathrm{Li}$, Zhu, Chen, Feng and Dimitrov. This is an open-access article distributed under the terms of the Creative Commons Attribution License (CC BY). The use, distribution or reproduction in other forums is permitted, provided the original author(s) or licensor are credited and that the original publication in this journal is cited, in accordance with accepted academic practice. No use, distribution or reproduction is permitted which does not comply with these terms. 